\title{
SAN AGUSTIN: INTERIORIDAD, REFLEXIVIDAD Y CERTEZA
}

\author{
Agustín Uña Juárez \\ Universidad Complutense de Madrid
}

\begin{abstract}
RESUMEN
Este artículo investiga dos problemas principales en los conocidos argumentos de San Agustín en pro de la certeza, contra los escépticos. En realidad, son más bien dos niveles de una misma cuestión «metodológica»: la interioridad del conocimiento (y de la verdad) y la reflexión, como vía de certeza. Conclusión principal de este estudio es que ambas dimensiones son correlativas: la reflexión supone interioridad, y la interioridad exige reflexión, como vía de certeza. La última parte del artículo examina la doctrina agustiniana de la reflexión, en el contexto de su «filosofía del espíritu». La presente investigación intenta mostrar en este punto que, de hecho, San Agustín tematiza o supone, a lo largo de su obra (particularmente en De Trinitate y en Confessiones) tres grandes modos de reflexión, correspondientes a otros tantos modos de autoconocimiento del alma: el noticial, el cogitativo y el fenomenológico.
\end{abstract}

Palabras clave: San Agustín, certeza, escepticismo, método, reflexión, interioridad, conocimiento, Edad Media, subjetividad moderna.

\begin{abstract}
The present article researches into two main problems in St. Augustine's well known arguments of certainty, against the sceptics. Really, both problems are two different sides or levels of the same «methodological» question: the interiority of the knowledge (and the truth), and the reflection of the mind, as a way of certainty. A main conclusion of the present study is that both sides are correlative: reflection presupposes interiority, and interiority demands reflection, as a way of certainty. But, what is reflection for Augustine? The last part of this paper examines the Augustinian doctrine of reflection, in the context of his «philosophy of the mind». At this point, the present enquiry tries to show that our thinker supposes along his works (specially in De Trinitate and in Confessiones) three main kinds of reflection, according to three different modes of self-knowledge of the human mind: «notitialis», "cogitativa», and "phenomenological».
\end{abstract}

Key words: Saint Augustine, certainty, scepticism, method, reflection, interiority, knowledge, Middle Ages, Modern subjectivity.

\section{PLANTEAMIENTO}

Es generalmente reconocida la original aportación del Hiponense a la cuestión de la certeza. Constituye un notable hito en el compromiso teórico de fundamentar el conocimiento. Su reflexión abrió nuevas vías que comportan todo un giro de la filosofía. Retorna a la vida originaria del espíritu como reducto primordial e inviolable de certeza. De modo que, para él, la seguridad del cono- 
cimiento se basa radicalmente en la certeza de sí. ${ }^{1} \mathrm{El}$ presente estudio examina algunos de sus supuestos e indaga las condiciones teóricas que hicieron posible ese nuevo tratamiento de la cuestión. ${ }^{2}$ Examina particularmente la relación entre la gnoseología interiorista y la reflexividad del espíritu como método de certeza. Se trata de una aportación agustiniana de gran repercusión histórica. En la cultura meditativa del medievo y en el giro subjetivista del pensamiento moderno resuena el eco de su filosofía del espíritu y de su metodología reflexiva. ${ }^{3}$

Para poder apreciar toda la innovación de Agustín, habría que examinar tres dimensiones capitales del problema. Son las vertientes metodológica, (auto)biográfica y programática de su planteamiento y solución. Una breve presentación de cada una, como primer acceso, nos permitirá delimitar aquí nuestro estudio y plantear con toda claridad la cuestión.

1. Comencemos por la vertiente metodológica. El vuelco fue aquí completo al recurrir nuestro pensador a un poder peculiar del espíritu. En virtud del mismo, la mente puede verse, estar cabe sí, asistir despierta a su propio devenir y autoexperimentarse al girar sobre sí y volver sobre los hechos radicales de la autoconciencia o realidades primordiales en la conciencia de sí. Más aún. No sólo le permite vivir y revivir su propio mundo interior, por «introspección» o mediante una experiencia fenomenológica y descriptiva de sí misma, sino también autoexaminarse teóricamente - «de animi sui natura cogitare»— ${ }^{4}$ para definir su naturaleza y saber lo que es. Supone todo esto una conciencia propiamente reflexiva de la mente, que podríamos designar con el nombre cualitativo de «reflexividad». Interesa conocer sus modalidades y mostrar el decisivo papel que le confiere Agustín, en el marco de la filosofía del espiritu que opera en su base. Hay ya una cierta trayectoria en el estudio actual de esta cuestión. Examinaremos todo esto en el punto tercero de este estudio.

1 La historia del escepticismo y su debate cambió de signo con el pensador de Hipona. Por lo cual, el estudio del mismo ha de abrir capítulo aparte con la reorientación interiorista y reflexiva que le dio Agustín. Su intento distintivo se tradujo en toda una nueva argumentación reflexiva, desde una filosofía del espíritu, y basada en un retorno de autorreconocimiento por el propio sujeto de los hechos más radicales del yo: ser, pensar, recordar, dudar, vivir y querer o amar. Pone en juego el poder «reflexivo» del «ánimo». Lo que le permite alcanzar y escllarecer diominios primordiales del mismo, con sus «posesiones» originarias de verdad, y los hechos radicales que constituyen el yo como tal, en su misma subjetividad. Su gran hallazgo fue este: la reflexividad del yo permite un reconocimiento de la verdad inmune de todo error.

2 La investigación viene reconociendo la originalidad del Hiponense en este problema. «El haber buscado el punto de apoyo para la investigación y fundamentación de la verdad en la experiencia interna es mérito insigne de San Agustín» (Capánaga, V., «San Agustín en nuestro tiempo», en Alugustinus, 2(1957), 155-175, cit., 155). Menciona seguidamente un expresivo párrafo de H. Heimsoeth sobre la fecundidad medieval del pensamiento agustiniano de la interioridad (cf. Los seis grandes temas de la metafísica occidental, Madrid, Rev. Occid., 1946, 145). Alude también Capánaga a la idea de espíritu, operante en la nueva orientación de Agustín (cf. pp. 158 ss.). Poco antes, en uno de sus más penetrantes estudios, L. Cilleruelo llamaba la atención sobre el particular. Cree que el Hiponense ve en los «Académicos» la oportunidad «para examinar los fundamentos de la vida interion». Y realiza una «retirada estratégica» hacia el mundo inatacable de la experiencia interna del yo. El resultado es totalmente original: «Agustín implanta un método constructivo, una fórmula fundamental y fecunda: el saber cierto que el alma tiene de sí misma es el origen de toda certidumbre y el centro de la seguridad absoluta, infalible, indudable». Todo esto implica o supone «un cambio radical producido en la marcha de la filosofía» (Cilleruelo, L., «La Memoria sui», en Giom. d. Metaf., 9(1954), 478-492, cit., 480, 481, 482).

3 «El método fenomenológico se mueve íntegramente en actos de la reflexión» (Husserl, E., Ideen..., \& 77, trad., México, FCE., 1985, 172). El contexto explica esa frase crucial en sentido bien diverso del realismo de Agustín, pero no tan ajeno a la vía subjetiva que ambos pensadores practican. Sobre la reflexión trascendental de Kant, cf. Crítica de la razón pura, A 260=B 316, trad. esp., Madrid, Alfaguara, 1978, 276 ss.

4 De Trin., XIV, $5,8$.

5 La mente vuelta sobre la propia mente: «Mens non videtur nisi mente» (De Gen. litt., XI, 21). El intelecto se entiende a sí mismo (In Io., 47, 3). 
2. Pero esa reflexividad presupone ya adquirido todo el significado teórico de la interioridad en orden al conocimiento y a la verdad. Más aún. Supone ya operada una previa inserción del problema de la certeza en ese mismo dominio de la interioridad gnoseológica. Este contexto teórico de juventud enmarca la vivencia y el relato de un problema convertido en odisea del alma. Pasó, así, de la consideración fría al planteamiento cálido, y del universal abstracto al drama personal. La cuestión se hizo en él otra cosa: peripecia de su «peregrinatio animae» y episodio culminante de su experiencia interior, radicado en la subjetividad de un yo.

Todo esto exige adentrarnos con decisión en el mundo teórico y «confidencial» de Agustín, dentro del marco gnoseológico que sus varios relatos expresan o suponen. El escrito clave es aquí, obviamente, las Confesiones. Esta vertiente propiamente subjetiva e interiorista del problema agustiniano de la certeza la denominamos dimensión (auto)biográfica, por ser, a la vez, hecho vivido y hecho narrado por el propio Agustín. Dicho en breve: la reflexividad del espíritu supone interioridad. El drama agustiniano de la certeza se deja comprender en toda su magnitud teórica como un episodio capital de la mente vivido y revivido dentro de toda una gnoseología interiorista que las Confesiones suponen. La examinaremos en el punto segundo de este estudio.

3. La dimensión programática está presente y operante en la intención del joven Agustín. Se refiere directamente a Contra Academicos. Indica el sentido final del debate frente al «verosimilismo», al probabilismo o al derrotismo extremo de que nada nos es dado conocer. Su autor advierte que sólo la derrota incondicional del escepticismo le permitirá ganar, como viable, la formulación misma de su propia filosofía. Es decir, el proyecto de una síntesis convergente de racionalidad platónica y creencia revelada. ${ }^{6}$ Pues entre ambas sólo cabe, para Agustín, la vía de la concordia. Pero este programa exige una purificación previa de la vieja Academia de su extravío escéptico —o de su proceder esotérico- y recuperar al verdadero Platón, o sea, la doctrina de un mundo inteligible e ideal, justamente aquella con la que se ha de dialogar. A esa purificación doctrinal se ordena todo el debate. ${ }^{7}$

La filosofía de nuestro pensador nace así con propósito decididamente dialogal, acorde con el género literario mismo del diálogo en el que comienza a expresarse como filósofo novel. ${ }^{8}$ Es decir, mediante la combinación de dialéctica y retórica de una conversación constructiva, en el intercambio de un diálogo. Por eso, la resonante "laus Platonis» que aquí entona Agustín no es nada casual. ${ }^{9}$ Será tan permanente y continua como su mismo programa filosófico, pues pasó toda su vida «convirtiendo» a los platónicos. ${ }^{10}$ Y culminará en el magno diálogo de La ciudad de Dios, donde, por

$6 \ll$ «.. non iam sola fide, sed certa ratione» es la fórmula en De ord., II, 19, 50.

7 Que la discusión antiescéptica dé paso a todo un programa filosófico lo indica el propio Agustín a lo largo de la obra, pero de modo más explícito al concluirla, en un texto que se considera emblemático: Contra Acad., III, $20,43$. Pretende conocer también, «intelligendo», de la mano del platonismo, aquello mismo que acepta «credendo». Y Sto. Tomás aprobará gustoso este proyecto (cf. S. theol., I, 84, 5, resp.; De ver, XXI, 4, ad 3um.).

8 Cf. Fenretti, S., «ll giudizzio....» (ver bibliogr. final). Indica también el aspecto conceptual y terminológico de la obra, primer ensayo de un lenguaje filosófico (p. 162). Continuidad histórica significa recuperar la verdadera tradición platónica, es decir, las doctrinas de Platón y Plotino, protagonistas de una «vera philosophia» (p. 165).

9 Platón convierte en verdadero y grande todo cuanto dice (Contra Acad., III, 17, 37). Agustín resume su doctrina de la realidad inteligible como propuesta platónica básica. Y Plotino es como Platón redivivo. «... ut in hoc [Plotino] ille [Plato] revixisse putandus est» (ibid., III, 18, 41).

10 Véase, entre tantos lugares, junto al texto antes mencionado, De vera rel., IV, 6-7; De doctr. christ., II, 60, texto clave y voz autorizada para el medievo en cuanto a la actitud frente a la cultura greco-rromana. 
cierto, el debate antiescéptico permanece abierto. ${ }^{11}$ Convencido Agustín, desde su primer encuentro con «los platónicos», de que sólo ellos tienen la clave de la verdad racional, Contra Academicos se apresura a entablar el diálogo de la verdad con el verdadero Platón. ${ }^{2}$ El libro VIII de La ciudad de Dios explicará por qué prefirió el platonismo como interlocutor. ${ }^{13}$ Pero antes hay que recuperarlo del desvarío «académico», para que pueda asistir al diálogo y permita abrir un vasto programa teórico de por vida. ${ }^{14}$ Es la dimensión programática del problema.

Éste es el planteamiento nítido de esta investigación. Razones de espacio fuerzan a omitir este último punto. Pero hemos de obviar ciertas dificultades de principio, lo que permite, al propio tiempo, precisar el significado teórico de esta notable cuestión. «Mirabilis quaestio», oiremos decir a nuestro pensador.

A. Nos preguntamos, ante todo, si el debate de la certeza constituyó un problema verdaderamente filosófico para el gran Doctor. Ciertos intérpretes sostienen que no, por considerarlo un fideísta. ${ }^{15}$ Realmente, lo hubiera sido si sus razones de certeza en verdad no lo fueran, sino más bien testimonios externos de fe, de Biblia, de tradición o de autoridad. Sin embargo, no es posible aducir un solo texto de Agustín en sentido fideista. Porque empeñó su vida en demostrar lo contrario, es decir, en proponer argumentos racionales de gran valía teórica, a los que nos referiremos luego. La reivindicación de una razón cierta la encomendó Agustín al esfuerzo argumentativo de la propia razón. Para otros, Agustín en este problema - y en todos los demás - es un teólogo, no un filósofo. ${ }^{16}$ Algunos ven en este prejuicio, que jamás examinaron (por eso es prejuicio), la mejor excusa para el desconocimiento o la omisión. Dos cosas, al menos, parecen claras: 1) que el propio Agustín no siempre facilita las cosas para entender con precisión su proyecto y distinguir planos de conocimiento o para mantener las distinciones que él mismo formula. 2) Que ciertos tramos de su

11 En Retract., I, 1, 4 parecería revisar esta alabanza y retirarla. Llama «impio» nada menos que a Platón. Pero, en realidad, la mantiene, pues allí mismo exalta su propuesta de un mundo inteligible: «Nec Plato quidem in hoc erravit, quia esse mundum intelligibilem dixit» (ibid., I, 3, 2). Algo que habría de tenerse en cuenta cuando se habla de retirada de lo griego y platónico en el último Agustín. No hubo tal.

12 Para la actitud ante el platonismo, cf. Pegueroles, J., «La patria y el camino...», en Espíritu, 27(1978), 47-75.

13 Los platónicos aciertan, dice Agustín, en su triple y ajustada idea de Dios, en respuesta a las tres partes o dimensiones problemáticas de la filosofía helenística -lógica, física y ética - tripartición que, por cierto, Agustín, como todos en su tiempo, creía provenir del propio Platón. Ese acierto teológico lo compendia Agustín en célebres fórmulas. Según Platón, dice él, Dios es: «Causa constitutae universitatis et lux percipiendae veritatis et fons bibendae felicitatis» (De civ. Dei, VIII, 10, 2) - «Causa subsistendi, ratio intelligendi, ordo vivendi» (ibid., VIII, 4) -«Ipse quaeratur, ubi nobis secura sunt omnia, ipse cernatur, ubi nobis certa sunt omnia, ipse diligatur ubi nobis recta sunt omnia» (ibid.) - «Finis actionum, causa omnium naturarum, lumen omnium rationum» (ibid., 8, 4) - «Deus, sine quo nulla natura subsistit, nulla doctrina instruit, nullus usus expedit» (ibid.) - «Platonici... qui verum Deum, et rerum auctorem, et veritatis illustratorem, et beatitudinem largitorem esse dixerunt» (ibid., VIII, 5).

14 En carta a Hermogeniano reiteró Agustín que su intento en este primer escrito es rescatar lo más auténtico («sincertuml») del platonismo, al verdadero Platón (Ep. I, l). Y se alegra por eso de haber superado esa ominosa red , «odiosissimum retinaculum", que lo impedía $(1,3)$.

15 Así lo interpreta, sin base, R. H. Popkin en el libro que mencionaremos a continuación. El propio É. Gilson pudo dar pie a visiones deformadas así, por el teologismo estrecho en que aprisiona a Agustín. Sin fundamento, lo vio también como fideísta Oggioni, E., S. Agostino filosofo e pedagogista, Padua, Cedam, 1949. Interpretación infundada.

16 Interminable debate que se renueva al interpretar la doctrina agustiniana de la historia y donde las opiniones están claramente divididas. Un ejemplo: para K. Löwith se trata de un discurso teológico. No anda lejos de reiterar eso mismo, en términos más generales, Mondin, B., Il pensiero di Agostino. Filosofia, teologia, cultura, Roma, Città Nuova, 1988. La «svolta teologica» que ve en Agustín implicaría una mengua del esfuerzo racional. Mondin parece rebajarlo en demasía y socavar su autonomía. $Y$ dígase otro tanto en cuanto al influjo del platonismo. 
reflexión responden, pese a todo (y pese a él mismo), a un poderoso ejercicio de estricta racionalidad («liquida ratione», «subtilissima ratione»), con independencia de toda subordinación teológica a fines ulteriores de piedad. ${ }^{17}$ Sin razón válida y autónoma no hay filosofía. ${ }^{18}$ Pero Agustín reivindicó, pese a ciertos supuestos de teólogo, la validez autónoma del espíritu en la raíz primordial del conocer. ${ }^{19}$

Ciertos pensadores orientaron también la filosofía a otra cosa, por ejemplo, a una medicina de las dolencias de la Humanidad. Descartes y Comte descuellan aquí. Y hasta los neopositivistas, vendedores de palabras, insisten er la terapia filosófica y se presentan igualmente como curanderos de los hombres. Hoy, sin embargo, consideramos filosóficas sus propuestas con independencia de toda superchería o adherencia de las mismas. Volviendo a Agustín, si hay un problema netamente filosófico en su pensamiento, ése es justamente el de la certeza. Signo inconfundible de su talante filosófico y crítico (M. Baumgartner). De nadie tomó la solución. Nadie lo resolvió por él. Más aún. Durante toda su vida mantuvo viva esta reivindicación capital.

B. Preguntamos también qué puesto ocupa este problema en su filosofía ¿Es algo meramente ocasional? En realidad, traspasa el mero episodio coyuntural de su borrascosa juventud. ${ }^{20}$ Y es problema permanente, el más grave riesgo que corrió su «ánimo». ${ }^{21}$ Lo encaró al comienzo mismo de su carrera y a lo largo de toda ella. Es dictamen inapelable sobre la razón, del que depende todo su pensamiento. «Conocemos la verdad: he aquí el hecho básico en el que se apoya la filosofía de San Agustín». ${ }^{22}$ Cuestión crucial, pues. En esto sí se parece a Descartes (o viceversa), con quien se le suele comparar. Para ambos la certeza es la cuestión inicial, decisiva, del pensamiento como tal, del edificio filosófico. Convienen en llevar a la interioridad solitaria la reflexión del problema y ver en la autoconciencia «el primer absoluto lógico y metódico». ${ }^{23}$ Pero

17 A juicio de Ch. Boyer, Agustín examina filosóficamente en su obra todos los grandes problemas del pensamiento. Y los enumera (cf. Boyer, Ch., Sant'Agostino..., 220-221).

18 «L'autonomie scientifique de la philosophie est essentielle à sa rigueur et à sa valeur critique» (Van Steenberghen, F., Introduction à l'étude de la philosophie médiévale, Lovaina-París, Nauwelaerts, 1974, 110). Autonomía que, pese a todo, ha de suponer también É. Gilson cuando habla de «espontaneidad», por la que todo conocimiento se produce, en agustiniano, «au dédans et du dédans», sin nada exterior, como veremos luego. Cuando el presente estudio hable de «autonomía» nunca se entenderá en relación a lo superior, de lo que siempre depende la mente iluminada, asistida, de Agustín. Excluye que la determinen motivos de estricta revelación, estricta creencia y estricta autoridad, impropios de la filosofía. En principio al menos, Agustín distingue bien en Conta Acad., III, 20, 43: pensar por razón y pensar por autoridad. Más problemático es que luego mantenga tan nítida separación de campos. Autonomía en Agustín siempre implica independencia y no-ser-determinada la mente por algo exterior-inferior. Y quiere también decir que, sin merma de la iluminación, pertenece al alma como tal la posesión originaria y visiva, intuitiva, de verdades primordiales que son como su «dote» natural ( «hoc ei naturaliter inditum est»). La mente está inserta irrevocablemente en la verdad. Lo cual es reconocido por vía de reflexión como método infalible de certeza. Volviendo sobre esa radicación interior.

19 El providencialismo entusiasta con que Agustín interpretó la experiencia de su propia conversión le llevó a afirmar que «los hombres somos demasiado débiles para alcanzar la verdad con la sola razón, liquida ratione» (Confess., VI, 5, 8. Lo repite en otros lugares). $Y$, en consecuencia, hace de Dios causa inmediata del efecto que sus lecturas platónicas le produjeron. Pero esta «radicalidad del converso», que A. Trapè enumera entre las «limitaciones» de tan gran pensador, queda desmentida por su ejercicio filosófico de hecho, basado en pura razón («liquida ratione»). Véase: Trapè, A., S. Agostino..., 431. Lo que los filósofos dicen de sus doctrinas hay que atemperarlo a menudo con lo que realmente hacenl cuando las piensan.

20 Es una de sus grandes preocupaciones teóricas de por vida, como recuerda Gilson, É., Introduction..., 53-55.

21 «... foveam periculi mei» (Confess., VI, 3, 3).

22 Boyer, Ch., Lî́ée de vérité..., 12.

23 Cilleruelo, L. «La Memoria...», 483. 
en la función de la duda difieren. Descartes creyó que la duda exasperada produciría la verdad. Agustín no, jamás. La certeza es para él previa a toda duda por la inserción originaria del alma en la verdad. ${ }^{24}$ La verdad posibilita la duda y la duda supone verdad. Aun el caso extremo de la duda es revelador de verdad. Ni pretende nuestro pensador fundamentar un sistema, como lo intenta el francés. Tampoco la frialdad cartesiana de un hombre previamente instalado en la seguridad («el filósofo de la estufa», pez frío) es equiparable al drama ardoroso, incandescente, de Agustín ante el fracaso desesperado de su razón («desperabam»). Ni el contexto pirrónico, exterior, de la duda cartesiana es similar al desafío interior de Agustín. ${ }^{25}$ Su problema reviste alcance humanista. Se halla en juego el hombre mismo. Y recuperar la certeza es devolverle razones de vida, el sentido de su existencia. Así lo vivió él mismo. Y de ahí su preocupación ética al afrontar el escepticismo.

C. Finalmente, ¿cuál es la magnitud y èl horizonte del problema? Su significado es hondo. Y de gran trascendencia teórico-histórica para el propio Agustín y para el devenir del pensamiento en su conjunto. De grandiosa contienda ( «magna controversia») la califica él mismo; en ella está en juego la vida y el alma. ${ }^{26} \mathrm{Y}$ su debate es mucho más que verbal. ${ }^{27}$ Pues nuestro gran cometido es buscar la verdad. ${ }^{28}$ En cuanto al pasado filosófico, Agustín ratifica, de forma crítica y positiva, que el pensamiento antiguo no concluyó en el fracaso de la razón escéptica que los esquemas hegelianos podrian sugerir. Por el contrario, confirma la validez de la razón. Y ve en el problema una urgencia clara de su tiempo. ${ }^{29}$ Por su intervención doctrinal, no habrá verdaderos escépticos medie-

24 «Hinc admonemur esse nobis in abdito mentis quarundam rerum quasdam notitias, et tunc quodammodo procedere in medium, atque in conspectu mentis velut apertius constitui, quando cogitantur» (De Trin., XIV, 7, 9). San Agustín bucea, de este modo, en la «intima scientia», en la «sedes animae», en el «abditum mentis» o en los «latebra spiritus», recovecos y profundidades gnoseológicas del alma. Y halla aquí la base primera de cuanto conocemos por la mirada más manifiesta («apertius») de la mente. Esto radical y originario lo tiene el alma «penes seipsam». Y le pertenece por naturaleza: «hoc ei naturaliter inditum est». A veces habla de lo «impreso» naturalmente en el alma. Por eso, la verdad la fundamenta el mero autorreconocimiento de sí. En consecuencia, aquello «manifestísimo», de lo que se ha de partir -capaz de soportar la extrema tensión teorética de afirmar lo más alejado de toda experiencia, el ạbsoluto- es justamente lo interior. Para Aristóteles, por el contrario, lo más manifiesto, en lo que todos convienen, es lo sensible, material, mutable y exterior, dado de forma inmediata por el sentido. Es la gran opción gnoseológica de la que el libro XII de la Metafisica alza su búsqueda de la causa suprema hasta hallarla en el Primer Motor. Agustinismo y aristotelismos de toda especie tienen aquí una línea divisoria, quizá la más decisiva, en lo que cabe llamar la antropología del conocimiento, «metafísica de la verdad» (E. Forment) o gnoseoontología radical.

25 Una larga tradición de estudios comparativos, que arranca ya del siglo XIX, aproxima a ambos pensadores. Pero no todos están dispuestos, comenzando por Pascal, a ver en Agustín un precedente de Descartes en este problema, como lo hacían L. Blanchet y Gilson, É., René Descartes. Discours de la méthode, text et commentaire, París, Vrin, 1925, 295-298. Ya Ch. Boyer señalaba diferencias, en lo que le sigue también Sciacca, M.F., San Agustín...(ver bibliogr.), espec. pp. 358 ss. Para cautelas al respecto cf. art. de E. Frutos, mencionado en bibliogr. Véase Gouhier, H., Cartésianisme et Augustinisme au XVIle siècle, París, Vrin, 1978. El último gran estudio comparativo es el de St. Menn, citado en bibliogr. final.

26 «e vita nostra, de moribus, de animo res agitur» (Contra Acad., II, 9, 22).

27 «Non est ista, inquam, mihi crede, verborum, sed rerum ipsanum magna controversia» (Contra Acad., II, 10, 24).

28 «... negotium nostrum non leve aut superfluum, sed necessarium ac summum esse arbitror, magnopere, quaerere veritatem» (Contra Acad., III, 1, 1).

29 En nombre de la ciencia misma, hay que llevar a los hombres de hoy, dice Agustín, a la esperanza de poder superar el impedimento del escepticismo. He aquí sus palabras, en carta a Hermogeniano, del año 386/387, en pleno debate con los «Académicos»: «... reducendi mihi videntur homines, si quos Academiconum per verborum ingenium a rerum comprehensione terruit sententia, in spem reperiendae veritatis, ne id, quod eradicandis altissimis erroribus pro tempore accommodatum fuit, iam incipiat inserendae scientiae impedimento esse» (Ep. I, 1). 
vales. ${ }^{30}$ Porque sus argumentos hicieron del escepticismo «vía impracticable», en expresión de Parménides. ${ }^{31} \mathrm{Y}$ cuando la modernidad lo retoma, ${ }^{32}$ reencontramos la metodología interior en Descartes. Para él y para la modernidad de Kant o de Husserl dejó establecido Agustín que la fundamentación del conocimiento exige una vía reflexiva, un giro hacia la subjetividad. Sería, pues, inapropiado repetir el prejuicio de Hegel sobre el pensamiento postaristotélico o lo que ciertos «sabios» de ahora suponen sin más: que Agustín pueda omitirse sin pena ni daño para la historia de la filosofía en el debate de la certeza.

\section{DIMENSIÓN (AUTO)BIOGRÁFICA: INTERIORIDAD Y CERTEZA.}

Sólo la gnoseología interiorista del Hiponense da sentido pleno a su drama interior de certeza. Y posibilita su nueva argumentación reflexiva contra los «Académicos». Tal es la densidad de su experiencia y de su relato. Porque hay en este problema una primera evidencia de la que se ha de partir: la cuestión de la certeza fue ante todo hecho vivido y hecho narrado por el propio Agustín. Es lo que denominamos dimensión (auto)biográfica. Lo relató varias veces. Porque Agustín, como el propio Descartes --en sentido muy diverso, también aquí- anduvo siempre en boca del mismo Agustín. De modo que sus primeros escritos se interpretan hoy también en senti-

30 A excepción, quizá, de personajes aislados o poco visibles. El mundo latino medieval formuló más bien cautelas de la razón ante el ser y la existencia de Dios. Platón afirma que el Bien está más allá de la mente («epékeina noư»). Trascendencia que subraya Plotino en la relación de la segunda hipóstasis -la Inteligencia - con la primera o el Uno. Es tesis capital del neoplatonismo que el Absoluto es inabarcable e indecible («árreton»). La teología negativa del PseudoDionisio proyectará sobre el medievo el desarrollo de estos supuestos que también Agustín acepta, pues si lo abarcas, no es Dios («si comprehendis, non est Deus»), del que se sabe mejor no sabiendo («qui scitur melius nesciendo»), pues a la mente sólo le queda constatar «quomodo eum nesciat». Dios es inefable (In Ps., 85, 12). Véanse a este respecto: Heiser, J. H., «Saint Augustine and the negative theology», en The New Scholast., 63, 1(1989), 66-80, quien insiste en la dependencia de Plotino y su componente mística. Carabine, D., «Negative theology in the thought of Saint Augustine», en Rech. $d$. Théol. Anc. Méd., 69(1992), 5-22, corrige al anterior y rebaja el sentido apofático en la teología de Agustín. La retirada de la razón en las pruebas demostrativas de la existencia de Dios, parece haberse iniciado entre las últimas décadas del siglo XIII y las primeras del XIV, confirmando así el sentido «moderno» de esa época y que culminará, de momento, en la postura de Ockham, recluido en lo probable, en ciertas cautelas ante la relación de causalidad, etc. Véase Philippe, M.-D., De l'être à Dieu. Topique historique, II..., París, Téqui, 1978, 645 ss. Pero nada desmiente una vigencia capital del medievo: la confianza en la razón, irrenunciable para todo hombre, incluso en teología (cf. Ghisalberti, A., Medievo teologico, RomaBari, Laterza, 1990, 4).

31 El docto abate polaco K. Michalski insistió en ciertas corrientes escépticas que atravesarían el siglo XIV, precisamente bajo el influjo de Agustín, tan antiescéptico él. Habla del retorno del escepticismo ya por entonces. Pero abusa de la palabra «escéptico». Dilata su concepto y lo extiende a prevenciones y recortes de la razón, en sentido nominalista, que para nada excluyen la confianza de los medievales en la razón (Cf. estudios editados por K. Flasch en la obra: Michalski, K., La philosophie au XIVe siècle, Francfort, Minerva, 1969). Un volumen conmemorativo del esclarecido abate apareció en Amsterdam, Grüner, 1988. Pero sus propuestas no reciben la clarificación que precisan.

32 Cf. R. H. Popkin, La historia del escepticismo desde Erasmo hasta Spinoza, México, FCE., 1983. Libro no siempre seguro en cuanto a la exactitud de los conceptos. Por lo cual hace de San Agustín a un fideísta.

33 Cf. McWilliam, J., «The Cassiciacum Autobiography», en Studia Patr., 18,4(1990), 14-43. Aproxima entre sí primeros escritos y relato de las Confesiones, particularmente en el proyecto filosófico de armonizar razón y fe con el que concluye Contra Academicos, como ya vimos. Confirma, una vez más, la fidelidad histórica de las Confesiones - mayor aún, dice él- que la de sus primeros escritos. Recuerda en detalle el viejo debate al respecto. También: Dewart, J. M. W., «La autobiografía de Casiciaco», en Augustinus, 31(1986), 41-78. 
do autobiográfico. ${ }^{33}$ En ellos evoca este supremo debate de su alma. Es lo que venimos denominando sus «pequeñas Confesiones». ${ }^{34}$

Pero interesa el relato mayor. Supone teóricamente ganado el dominio interior como realidad privativa del hombre. Las Confesiones son, por eso, teoría y práctica de la interioridad. Además, en ese dominio interior inscribe la cuestión de la certeza, convertida en peripecia del yo. Y si la verdad fundamenta su certeza por autoconciencia y reflexividad, esto mismo presupone interioridad. Esa vía interior del conocimiento es operativa en las Confesiones. Son el ejercicio mismo de su filosofía, como su filosofía es la expresión teórica de su persona. Este admirable escrito no surge por casualidad. Su honda innovación literaria emerge de una decisiva reinterpretación del hombre como ser dotado de interioridad. Agustín descubrió aquí el lugar del encuentro con los valores decisivos del hombre, especialmente el de la verdad.

Estamos, pues, ante una interioridad gnoseológica o una gnoseología interiorista. Céntrico en su relato - como en sus primeros escritos - es el problema del verdadero conocimiento. $\mathrm{Y}$ presenta su odisea interior como peregrinación en busca de la verdad. Ésta es la clave interpretativa que Agustín mismo propone en la hermenéutica de su propia alma. Todo se orienta a la posesión de la sabiduría y de la verdad. Su pérdida, su búsqueda y su recuperación marcan sentido. Cabe hablar de «gnoseologización». Interioridad se torna drama de la verdad. ${ }^{35} \mathrm{Su}$ doble hallazgo en los libros platónicos - realidad inteligible e interioridad anímica - le devolvió la posibilidad misma de pensar. Y la convicción de que el hombre interior es el ámbito propio del conocimiento y de la verdad. Por eso las Confesiones, verdadero compendio doctrinal del Agustín juvenil, dan a la cuestión de la certeza toda la densidad gnoseológica ganada ya por su primera filosofía al colocar en la interioridad la consumación del conocimiento y de la verdad.

Sólo resta comprobar ambos puntos: cómo Agustín refiere siempre al interior el mundo complejo del conocimiento y los varios matices de la verdad.

1. Conocimiento e interioridad. Todo conocimiento se consuma, a juicio del Hiponense, en el dominio interior, aunque lo inicie una «admonición» exterior y remita a una luz superior. La consigna, «a visibilibus, ad intelligibilia», pasa siempre por la interioridad. Agustín lo expresa de forma dinámica y mística, al describir el recorrido del alma, vuelta sobre sí y en ascenso a la verdad. El comienzo de esta vía es la interiorización, el retorno a sí misma del alma: «intravi in intima mea». Y su final está en la «inconmutable verdad».$^{36} \mathrm{Y}$ el proceso dis-cursivo es un completo despliegue

34 Uno de ellos, del año 391, dice: «Con frecuencia me parecía imposible encontrarla [la verdad], y mis pensamientos vacilantes me llevaban a aprobar a los Académicos... Ante mí se abría una selva inextricable, y vacilaba y me faltaba decisión para penetrar en ella. Mi alma se agitaba sin descanso en medio de todas estas cosas, con ansias de encontrar la verdad (cupiditate reperiendi veri animus agitabatur)» (De util. cred., 8, 20).

35 Las expresiones «poseer la verdad» o «alcanzar la sabiduría» traspasan el significado, ya de suyo amplio, en el último helenismo. Y revisten matices éticos, gnoseológicos, eudaimónicos, teológicos y aun místicos... que, no exentos de cierta ambigüedad, explican una centralidad tan marcada como la que Agustín confiere a esas nociones, hasta vincular a ellas su suerte y su mismo destino personal. Por ejemplo, cuando dice que nadie que no sea sabio es feliz (De lib. arb., 9, 26). No basta para entenderlas con aducir meras «definiciones» de inspiración estoica por vía de Cicerón (conocimiento de lo divino y humano), como se suele hacer, cuando el joven Agustín centra su encendido discurso en torno a la «sapientia» y a la «verdad». Un ejemplo de estudio que no entra en cuestión — más bien se sale de ella— es el de Doull, J. A., «¿Qué es la sapientia agustiniana?», en Augustinus, 36(1991), 81-88.

36 «El inde, admonitus redire ad memet ipsum, intravi in intima mea duce te... Intravi et vidi qualicumque oculo animae meae supra eundem oculum animae meae, supra mentem meam, lucem incommutabilem, non hanc vulgarem et conspicuam omni carni, nec... Non hoc illa erat... Qui novit veritatem, novit eam... $\mathrm{O}$ aeterna veritas et vera caritas et cara 
del conocimiento: las disciplinas de la razón. Convierte este intento, tradicional ya desde el viejo pitagorismo a Varrón, en grados interiores del alma. ${ }^{37}$ Entiende, por eso, los «poderes» del alma («animae potentia») como un despliegue de sí misma en «grados» interiores que culminan en la visión de la verdad, con alcance y denominación estética, como modos de belleza. ${ }^{38}$

Pero la referencia a la interioridad aparece neta en las cuatro grandes modalidades del conocimiento humano: las del sentido, la imaginación, la memoria y la mente, que nuestro pensador entiende como otros tantos modos de «visión» o de «dicción». ${ }^{39} \mathrm{Y}$ aunque suele aludir sólo a dos, la visión del sentido y la visión de la mente, ${ }^{40}$ un pasaje de alto valor gnoseológico y estético incluye también la mirada de la fantasía o imaginación, el «inaginarium conspectum». ${ }^{41}$ Tenemos, así, tres modos de conocer algo bello: con la visión del sentido, la mirada imaginativa, el concepto del ánimo. Y añade también la presencia en la memoria. Este esquema de las cuatro grandes facultades y modos de conocimiento permite ordenar su doctrina gnoseológica y percibir su carácter interiorista. El alma es el protagonista exclusivo en todo conocimiento. ${ }^{42}$

aeternitas... et non erat prorsus unde dubitarem, faciliusque dubitarem vivere me quam non esse veritatem...» (Confess. VII, 10, 16. Subrayado mío). «... inveneram incommutabilem et veram veritatis aeternitatem supra mentem meam commutabilem. Atque ita gradatim a corporibus ad sentientem per corpus animama... et pervenit ad id quod est in ictu trepidantis aspectus» (ibid., VII, 18, 33). Recorrido místico y de marcado acento gnoseológico, habida cuenta de la amplitud del concepto de verdad. Véase el influjo de Plotino en un estudio, no excesivamente clarificador, de Cousins, E. H., «Intravi in intima mea. Augustine and Neoplatonism», en Arch. di Filos., 51(1983), 281-292. El descubrimiento de Dios está mediado aquí, dice el autor, por la epistemología platónica y su metafísica (p. 285). Y se sale de tema para hablar del eco de este «itinerarium mentis» en San Buenaventura. Véase O'Connell, R. J., St. Augustine's early theory of man, A. D. 386-391, Cambridge, Harvard Univ. Press, 1968, 1-28

37 La preocupación por las «disciplinae» y las artes es descollante en el Agustín juvenil. Fruto de ello es, sobre todo, su De musica. Para la teoría del raciocinio y su despliegue gradual, cf. De quant. an., 27, 52; De ord., II, 11, 30 y caps. ss. donde el «ordo studionum» deriva del despligue de la razón. A juicio de I. Hadot, contra H.-I. Marrou, es con Agustín con quien se constituye el ciclo de las artes. Véase Hadot, I., Arts libéraux et philosophie dans la pensée antique, París 1984, 25-60. A mi entender, está en lo cierto Marrou.

38 De quant. an., 33, 70. Cf. Camilloni, C., «Los siete grados ascendentes del alma en san Agustín», en Filosofar cristiano, 10,19(1976, 51-57.

39 «Dicere rem». «... quando enim concipis verbum quod proferas, rem vis dicere, et ipsa rei conceptio in corde tuo iam verbum est» (In IO., 14, 7). «Formata quippe cogitatio ab ea re quam scimus, verbum est quod in corde dicimus...» (De Trin. XV, $\left.1^{\circ}, 19\right)$. «Est verbum quod vere spiritualiter dicitur...» (In Io., 1,8)

40 «Visiones enim duae sunt, una sentientis, altera cogitantis» (De Trin., XI, 9, 16). Distingue, en lo que vemos, «alia corpore, alia mente» (Ep. 147, 16, 38). Al igual que en Platón, hay todo un amplio discurso agustiniano sobre la visión de la mente (cf. Cilleruelo, L.; «Detum videre en San Agustín», en Salmanticensis, 12(1965), 2-31; 13(1966), 231-281). En la base del orden inteligible está la Idea, que es visión. Su órgano visivo es la mente. Véase Paquet, L., Platon.La médiation du régard, Leiden, Brill, 1973. Pensar es ver: «... cogitatio visio est animi quaedam» (De Trin., XV, 9, 16). Pensar es decir: no un sonido exterior «sed eius rei quam videndo intus dicimus... et verbum verum nostrum intimum nisi nostra cogitatione non dicitur» (De Trin., XV, 14, 24 y 15, 25).

41 «Item cum arcum pulchre et aequabiliter intortum, quem vidi, verbi gratia, Carthagine, animo revolvo, res quaedam menti muntiata per oculos, memoriaeque transfusa, imaginarium conspectum facit. Sed aliud mente conspicio, secundum quod mihi opus-illud placet; unde etiam, si displiceret corrigerem. Itaque de istis secundum illam iudicamus, et illam cernimus rationalis mentis intuitu [...] aliter figurantes animo imagines corportun, aut per corpus corpora videntes; aliter autem rationes artemque ineffabiliter pulchrum talium figurarum super aciem mentis simplici intelligentia capientes») (De Trin., IX, 6, 11). Subrayo en el texto los cuatro grandes modos del conocimiento humano como modos de visión. Utiliza fórmulas precisas para designarlos. Y les da alcance estético. En De Gen. litt., XII, 8, 19, propone tres visiones: corporal, espiritual e intelectual, siguiendo la división tripartita (paulina) del hombre. En efecto, pocas líneas antes, establecía «tria genera visionum»: "per oculos», "per spiritum hominis», "per contuitum mentis» (ibid., XII, 6, 15).

42 Todas las novedades que surgen en el ánimo no se constituyen desde el exterior («foris peracta»), aunque pueda parecerlo, «sed intus omnino in ipso animo esse coeperunt» (De Trin., XIV, 8, 11). Son realidad exclusiva del ánimo. 
A. Aunque el sentir — nunca emplea «sensación»— se valga de un instrumento corpóreo, exterior e inferior, su afección nunca le alcanza. ${ }^{43}$ Más bien la conoce en cuanto que, en realidad, «no se le oculta». ${ }^{44}$ Y aunque la «admonición» exterior, como advertencia de retorno ( «reditus»), marque el inicio de la conversión, sin embargo, el conocimiento sensible es exclusivo del alma. Se realiza y consuma en el interior sin tomar nada del exterior. ${ }^{45}$ La mente ve en sí las "constantes del espíritu» (A. Messer) o «leyes» que le permiten, desde lo permanente, no ser «devoratus temporibus» y juzgar lo inferior. Y sólo ese juicio produce, dice, la verdad. La autonomía del espíritu (respecto de lo inferior) comienza ya aquí. ${ }^{46}$ Hay unas "pulchritudinis leges», interiores, que el alma, cual absoluto estético, posee ya cabe sí («penes seipsam», «apud te»). Su luz no viene de la cosa a través de la forma. Y, por tanto, nada exterior la determina al conocer. ${ }^{47}$

$\mathrm{B}$. El análisis prosigue al estudiar las imágenes que genera la sensación. Ocupan el interior, las cavidades maravillosas de la fantasía. ${ }^{48}$ Es el universo colorista animado por el poder fabulador de la imaginación. El recorrido de Agustín por este amplísimo y bello «almacén» confirma su gnoseología interiorista. Es parte notable de su fenomenología del hombre interior. Puede contemplar la belleza exterior sin salir de sí. ${ }^{49}$ Su análisis fenomenológico se prolonga e integra de modo natural en su célebre exploración de la memoria, que nuestro pensador entiende, ante todo, como poder evocador de lo sentido. Pone a mano y vuelve disponibles, sus correspondientes imágenes, allí depositadas y retenidas.

C. Los recintos inmensos de la memoria («lata praetoria», «ingens aula») le horrorizan. ${ }^{50}$ Permiten entrever la magnitud del hombre-abismo. ${ }^{51}$ Pues son tan inabarcables y sin confines como el viejo Heráclito intuyó ${ }^{52}$ Pero Agustín descubre aquí mucho más que un depósito de imágenes y

$43 \ll .$. a seipsa patitur, non a corpore» (De mus., VI, 5, I0).

44 «... sensum puto esse non latere animam quod patitur corpus...Sensus est certe omnis passio corporis non latens animam» (De quant. an., 23, 41; 25, 48). Y discute la definición. Siente el alma: «... sentire non est corporis sed animae per corpus» (De Gen. litt., III, 5, 7). Es el primer grado de la luz del espíritu (M. F. Sciacca). El cuerpo es mero instrumento, intermediario y nuncio deI alma «sentiens per corpus» (Confess., VII, 17, 23).

45 Lo inteligible «a nobismetipsis intus aspicitur in animo sine corpore» (Ep. 147, 1, 6). La verdad se percibe «pura mente» (De vera rel., 3, 3).

46 «Quoquo enim te verteris, vestigïis quibusdam quae operibus suis impressit [sapientia] loquitur tibi, et te in exteriora relabentem ipsis exterionum formis intro revocat, ut quidquid te delectat in corpore et per corporeos inlicit sensus, videas esse numerosum et quaeras unde sit et in teipsum redeas atque intelligas te id quod attingis sensibus corporis probare aut improbare non posse, nisi apud te habeas quasdam pulchritudinis leges ad quas referas quaeque pulchra sentis exterius» (De lib. arb., II, 16, 41). Para el sentido estético véase mi escrito Uña Juárez, A., Cántico del Universo. La estética de San Agustín, Madrid, Autor, 2000, 86 ss. Las «leyes» o normas estéticas, propiedades autónomas de la mente, son referente obligado para toda percepción de algo en cuanto bello. Y lo bello exterior tiene sentido admonitorio: avisa al alma para el retorno que inicia la "conversio». Textos próximos vinculan entre sí «visión de la mente» y razón judicativa, «iudex ration, cuyo juicio interior del alma, atribuyendo, establece la verdad.

47 Hablar de abstracción en Agustín es impropio, disparatado. Cf. Körner, F., «Abstraktion oder Illumination?...», en Rech. Augustin., 2(1962), 81-109.

48 La palabra «phantasia» es corriente en Agustín, con cierta proximidad a la memoria: «... cum per sensum corporis discimus corpora, fit eorum aliqua similitudo in animo nostro, quae phantasia memoriae est» (De Trin., IX, 11, 16).

49 Confess., $X, 8,15$.

50 Desde Confess., $\mathrm{X}, 8,12$ arranca su célebre análisis.

51 Ya P. Muñoz Vega se refería a ello (cf. Introducción..., 4). In ps. 41, 13: define qué es abismo, lo aplica al corazón humano: «QQuid enim est profundius hac abyssso?». Confess., XIII, 14, 15: «Interius nostrum, tenebrosum et fluidum». Véase Capánaga, V., «El hombre-abismo, según San Agustín», en Auglistinus, 20(1975), 225-252, espec. 231-237.

52 «... grande, profundum est ipse homo» (Confess., IV, 14, 22). «... nec ego ipse capio totum quod sum» (ibid., X, 8, 15). «... immensa ista capacitas memoriae meae» (ibid., $X, 9,16$ ). «... nimium mirabilis est animus iste atque ad horrorem stupendus» (ibid., XI, 21, 41). 
conceptos o la dimensión temporal del pasado. Un logro capital de su filosofía lo constituye su transformación del concepto de memoria. Amplió la dimensión real de la misma en sentido de presente y en sentido antropológico de alcance metafisico. ${ }^{53} \mathrm{Y}$ ve en la memoria una facultad («vis») decisiva de su gnoseología interiorista cuyo escrutinio las Confesiones profundizan, como esfera del conocimiento interior. ${ }^{54}$

D. En la visión de la mente culminan los modos de conocer. Agustín la entiende como autónoma, independiente de lo exterior-inferior. ${ }^{55}$ Lo que conoce y ve está en su interior. Ella misma es interior ${ }^{56}$ Como mente iluminada, asistida, sigue normas propias que le competen de suyo («sui iuris»). En la base de tal autonomía puso, de joven, el innatismo platónico que supone la preexistencia del alma. Pero más tarde rechazó esta doctrina «del noble Platón». ${ }^{57}$ Algunos hablan, con desdichado vocablo, de «inneismo», mientras otros lo explican por la idea de iluminación o por la propia interioridad anímica. El alma, en todo caso, encuentra en sí misma («penes seipsam»), en sus propios recovecos («abdita mentis»), ciertas «noticias» primeras como impresión natural ( hoc ei naturaliter inditum est»). Interioridad y autonomía se coimplican en la intuición del alma. Y, además, el conocimiento comporta siempre un autoconocimiento «noticial» del yo.

Pero el interiorismo gnoseológico del Hiponense lo confirma otro rasgo específico de la «visio mentis»: su carácter judicativo. La mente posee en sí misma criterios, normas o leyes («leges»), para juzgar lo inferior, nunca lo superior. ${ }^{58}$ Como en tribunal interior, ha de emanar un dictamen, una sentencia, de atribución. ${ }^{59} \mathrm{El}$ alma posee las normas reguladoras de ese juicio sin el cual no hay verdad. ${ }^{60}$ Toda verdad se expresa como atribución judicativa. Conocer es juzgar. ${ }^{61} Y$ ese juicio, que pertenece al ánimo («animus iudex»), se consuma en el interior. En conclusión, toda la escala del conocimiento tiene para Agustín, como propiedad especifica, el ser un proceso interior. Y el reconocimiento de su certeza exige por ello vía de reflexión.

2. Verdad e interioridad. Siendo la distinción recurso de comprensión, urge distinguir finamente los tres diversos sentidos en los que Agustín vincula entre sí verdad e interioridad. En primer lugar, es interior el evento mismo de la verdad, pues hizo del «intus» el lugar propio, habitáculo ( habitat»), de la verdad, donde «praesto est». ${ }^{62}$ La verdad es suceso del alma, acontecimiento inte-

53 Cf. Capánaga, V., «La estructura ontológica de la memoria Dei», en Estudio agustin., 12(1977), 367-392.

54 Agustín encomiaba el poder de la memoria ya en De quant. animae, 14, 23.

55 Descubrimos en nosotros más que aprendemos del exterior. Por eso, É. Gilson habla de «espontaneidad» del alma. En virtud de ella, todo conòcimiento del espíritu se produce en el interior y desde el interior, «au dédans et du dédans». Y se refiere también a «una irreductible espontaneidad» (Gilson, É., Introduction..., 93).

56 «... cum sit mens interior...» (De Trin., X, 8, 11).

57 Cf. De quant. an., 20, 34; Ep. 7, 2; De Trin., XII, 15, 24; Retr., I, 8, 2; 1, 4, 4. Admisión, crítica, rechazo.

58 «... animae iudicium» (De Gen. litt. imp. liber, V, 24). «... nuntiantibus sensibus iudex ratio» (Confess., X, 6, 10, cf. De lib. arb. II, 12,31). El «recte iudicare» pertenece a la mente, no al sentido (De civ. Dei, XI, 27, 2). «Sed sublimioris rationis est iudicare de istis corporalibus secundum rationes incorporales sempiternas...» (De Trin., XII, 2, 2).

59 «... quasi quodam naturali iure ferre sententiam» (De mus., VI, 4, 5).

60 «Viget et claret desuper iudicium veritatis, ac sui iuris [mentis] incomptissimis regulis firmum est» (De Trin., $\mathrm{XI}, 6,10)$. El «juicio de verdad» se fundamenta en ciertas reglas o «leyes» que a la mente le pertenecen de suyo, sin dependencia de lo exterior. Y en este sentido (sólo en él) puede hablarse de «autonomía».

61 También Aristóteles (Peri hermen., 1, 16 a 13-18: diairesis-syntheis, mediante el verbo ser). Y Sto. Tomás (S. theol., I, 85, 5: «Utrum intellectus noster intelligat componendo et dividendo»).

62 En infinitivo, «praesto esse» (De lib. arb., II, 12, 33). 
rior. ${ }^{63}$ En segundo lugar, su hallazgo o invención es también interior. Y puesto que el hombre no la crea, ni la constituye (determinando por la forma o siendo determinado por ella), ni la inventa, únicamente la halla. ${ }^{64} \mathrm{El}$ alma la descubre en sí misma ("penes seipsam») con su mirada u oyendo la voz del maestro interior. En tercer lugar, el reconocimiento de su certeza es igualmente interior, por reflexión del espíritu en un giro o «flexión» del yo sobre el propio yo, sobre los hechos primordiales de su misma yoidad subjetiva y real. El debate antiescéptico se resuelve en un autoexamen del alma o del yo como tal. La interioridad reflexiva re-conoce su propia autonoticia. Esto supone adquirida ya en sus primeros escritos esa misma interioridad gnoseológica que acabamos de recorrer y comprobar. En ella el relato de las Confesiones inscribe el problema de la certeza como un debate íntimo del alma de Agustín. En conclusión: si el evento y el descubrimiento de la verdad es interior, el reconocimiento de su certeza será por vuelta al interior como a un cierto absoluto gnoseológico radical. $\mathrm{Y}$ el nuevo método re-conoce la autonoticia interior, por vuelta al yo: mediante la interioridad reflexiva o la reflexividad del espíritu.

Las Confesiones inscriben su vivencia-relato en esta misma perspectiva. Era el otoño del 383. Un momento delicado en la evolución de su espíritu. Agustín es profesor de retórica en Roma. Le bastará un año para quedar doblemente decepcionado: del comportamiento incivil de los estudiantes - aquí llovía sobre mojado - y de la creencia maniquea. Y decide abandonar ambas, ciudad y secta, si bien, por razones prácticas, difiere romper con esta última. Se siente perdido, confuso, tras declinar hacia un vago racionalismo materialista e incluso acudir, llevado por la curiosidad, a magos y astrólogos: ${ }^{65}$ Sin referentes, como barco sin ancla, va a la deriva («fluitans»), agitado por un gran oleaje y sumergido en el abismo de un mar profundo. ${ }^{66}$ Acompaña a todo ello una gran conmoción, verdadera tormenta interior, ante la sospecha creciente de que al hombre le es imposible hallar la verdad. ${ }^{67} \mathrm{Su}$ decepción se transforma en el dolor del alma llamado angustia, llegando a la desesperación de la mente. ${ }^{68} \mathrm{Y}$ se adhiere al escepticismo ${ }^{69}$ Ciertos intérpretes se resisten a tomarlo en serio

63 «Noli foras ire, in teipsum redi, in interiore homine habitat veritas...» (De vera rel., 39, 72). Véase Kersting, W., «Noli foras ire, in te ipsum redi. Augustinus über die Seele», en Prima Philos, 3,3(1990), 309-331.

64 «... non alibi quam in animo nostro invenimus, neque id est invenire quod facere aut gignere» (De imm. an., IV, 6). «Cum vero de his agitur, quae mente conspicimus, id est intellectu atque ratione, ea quidem loquimur, quae praesentia contuemur in illa interiore luce veritatis, qua ipse qui dicitur homo interior inlustratur et fruitur» (De mag., XII, 40). Las cosas que no tienen imágenes sensibles, es decir, las inteligibles "per se ipsa intus cernimus» (Confess., X, 11, 18). La verdad ni la crea, ni la juzga, ni la corrige. La encuentra: «Non examinator corrigit, sed tantum laetatur inventor» (De lib. arb., II, 12, 34).

65 «... quos mathematicos vocant» (Confess., IV, 3, 4).

66 Situación (y simbología marina) reflejada en otra de sus «pequeñas Confesiones»: «At ubi discussos eos [manichaeos] evasi, diu gubernacula mea repugnantia omnibus ventis in mediis fluctibus academici tenuerunt» (De b. vita, 1, 4).

67 «Etenim suborta est etiam mihi cogitatio, prudentiores illos ceteris fuisse philosophos, quos academicos appellant, quod de omnibus dubitandum esse censuerant, nec aliquid veri ab homine comprehendi posse decreveram» (Confess., $\mathrm{V}, 10,19)$.

68 Él mismo habla de «languor animae meae» (Confess., V, 14, 25). Y alude a su «corazón miserable, lleno de inquietudes penosísimas, fruto del temor a la muerte y de mi fallido descubrimiento de la verdads (ibid., VII, 5, 7). Entiende su lucha como una preocupación dolorosa que le roía el alma (ibid., VI, 4, 5).

69 «... diu gubernacula mea repugnantia omnibus ventis in mediis fluctibus academici tenuerunt» (De b. vita, 1, 4). «Itaque, academicorum more, sicut existimantur, dubitans de omnibus, atque inter omnia fluctuans, manichaeos relinquendos esse decrevi, non arbitrans eo ipso tempore dubitationis meae in illa secta permanendum esse, cum iam nonnullos philosophos praeponebam» (Confess., V, 14, 25). Cuando su madre vino a su encuentro en Roma, lo halló sumido en la desesperación escéptica: «Et invenit me periclitantem quidem graviter desperatione indagandae veritatis» (Confess., VI, l, 1). «... ad illam ancipitem fluctuationem esse perductum» (ibid.). 
y rebajan su alcance. ${ }^{70}$ Pero la sostenida preocupación de Agustín y su empeño tan vivo en refutarlo, parecen contradecirlo. Y evidencian la profunda marca que el derrotismo ante la verdad dejó en su ánimo. ${ }^{71}$ En todo caso, la tentación escéptica, surgida ya en Roma, la arrastró a Milán, a donde Ilegó el otoño siguiente (384) como el nuevo profesor de retórica que ha de cantar -y mentir- las virtudes de los grandes. ${ }^{2}$

Advierte cuántas verdades admitimos a diario sin haberlas comprobado. ${ }^{73}$ Es la gota que comienza a horadar la piedra. Hasta el otoño del 386, operada ya su conversión, su mente experimenta una profunda mutación en dos dimensiones inseparables de la misma: la religiosa y la propiamente filosófica. Responsables decisivos de esta última - y, en buena medida, también de la primera - fueron ciertos libros de «los platónicos», cuya lectura provocó en su interior un «increíble» incendio. Lo reitera, con su ardor habitual, en otra de sus "pequeñas Confesiones». ${ }^{74}$ Por ellos venció el escepticismo. ${ }^{75}$

El drama de la certeza pasa, así, al segundo acto: su recuperación. Agustín halló en los platónicos su propia confirmación en la verdad. Ellos le proporcionaron dos certezas capitales que anhelaba: la percepción infalible del orden inteligible, la percepción infalible de la realidad interior. $\mathrm{Y}$ la combinación de ambas le disolvió toda duda. ${ }^{76}$ Más aún. Confirmó su vocación filosófica, iniciada en cierto modo, a sus 19 años, leyendo el Hortensio de Cicerón. ${ }^{77}$ Todavía más. Le marcó su programa filosófico personal, pues esos mismos pensadores aparecen como los interlocutores válidos para su proyecto de síntesis entre creencia y razón. Pero el quehacer inmediato es ahora, desde su primer escrito conservado, preparar ese diálogo de doble forma: fundamentando teóricamente la certeza y purificando el platonismo del devaneo «académico».

Concluyamos con una doble observación. En primer lugar, que la fundamentación teórica de la verdad le durará toda la vida. Tan en serio lo tomó ${ }^{78} \mathrm{Y}$, en segundo término, que el ajuste de ideas y la recuperación de la certeza son urgencia dominante y capital. Impulsan de modo destacado la odisea del joven Agustín, como una reconstrucción de la vida de la mente en el escenario del hombre interior. Ganar la verdad constituye la gran peripecia interior de Agustín. Fundamentarla, exigirá retornar a la verdad interior mediante un giro del espíritu sobre sí mismo, que llamamos «reflexión».

70 «... más que de un verdadero escepticismo, se trataba de una prudencia justificada después de la amarga experiencia maniquea» (Sciacca, M. F., San Agustín..., 48). Otros hablan de una mera simpatía.

71 Agustín veía entonces en los escépticos «a los verdaderos intérpretes de su estado de ánimo» (Trapè, A., S. Agostino..., 95). Acabamos oirle decir en un texto «dubitans de onnibus». «... diffidebam de inventione veri» (Confess., VI, 1, 1).

72 Confess., VI, $6,9$.

73 Confess., VI, $5,7$.

74 «... incredibile... incredibile... incredibile incendium» (Contra Acad., II, 2, 5). Su luz le descubrió la dimensión interior, echando a correr en dirección a sí mismo: «... prorsus totus in me cursim redibam» (ibid.). Y le descubrió la filosofía misma: «Tota se mihi philosophiae facies aperuit» (ibid., II, 2, 6).

75 Sciacca, M. F., San Aglistin..., 175.

76 Reentrando en sí mismo, — «intravi in intima mea»-, descubre una luz inconmutable que toda duda disuelve: «... et non erat prorsus unde dubitarem, faciliusque dubitarem vivere me, quam non esse veritatem» (Confess., VII, 12,.18). Inteligibilidad e interioridad le devuelven la posibilidad de pensar, superados su materialismo y su escepticismo ("molem istamp).

77 Confess., III, $4,7$.

78 Dicho sea por quienes opinan lo contrario, que el Hiponense no se tomó en serio la discusión antiescéptica, como dicen P. Brown y J. O’Meara, entre otros. Les contradice con buenas razones todo un estudio de A. M. Neiman, citado en bibliogr. final. 


\section{REFLEXIVIDAD, INTERIORIDAD Y CERTEZA}

El nuevo método reflexivo de Agustín se sigue, pues, de su concepción interiorista del conocimiento y la verdad, practicada en su relato. Por lo cual, interioridad y reflexividad son para él correlativas: reflexividad supone interioridad, e interioridad demanda reflexividad, como vía adecuada de certeza. El problema es ahora indagar su concepto ¿Hasta qué punto lo estudió expresamente Agustín? Porque, si bien no la nombra con esta palabra, el papel teórico que asigna a la reflexión es decisivo. La sitúa en la raíz misma del autoconocimiento: muestra y hace explícita la radicación en la verdad como absoluto infranqueable de la mente. Reconoce la verdad en que la mente ya está. Es la base de sus célebres argumentos.

Un análisis detallado de los mismos supera los límites de este estudio. Sólo cabe observar su regreso efectivo a «lo primero» (tò próton), como diría Aristóteles, lo que para Agustín es la realidad radical del yo. La verdad se fundamenta como cierta, al reconocer la mente su propia «noticia» o su «nosse se», por vía de reflexión. El Hiponense arguye que el yo se autoevidencia insuprimible como realidad existente y como sujeto. ${ }^{79}$ Que su subjetividad y su existencia reaparecen incluso frente a la duda o a todo intento de supresión. Borrarme como hecho supone reafirmarme como sujeto. Su realidad permanece incólume, firme en sus actos primordiales de existir, pensar y conocer, recordar y dudar, vivir, desear y amar. Es indestructible la certeza del propio vivir ${ }^{80}$ y la del propio pensar ${ }^{81} \mathrm{o}$ la de ser, vivir y entender ${ }^{82} \mathrm{e}$ incluso la del propio dudar. ${ }^{83}$ En De Trinitate retorna la triada ser, vivir y entender, que inmediatamente extiende también al vivir, recordar, entender y querer, pensar y saber, juzgar, como hechos indudables. ${ }^{84}$ Es toda la realidad radical del yo, reconocida como verdad autoevidente por la mirada de la reflexión, en la base del autoconocimiento que nos explicará Agustín. Interioridad y reflexividad se correlacionan mutuamente.

Un conocimiento íntimo ( intima scientia») nos certifica que vivimos. Contra esto nada pueden los argumentos escépticos. Y añade Agustín, en línea con su gnoseología interiorista, que aunque se discutan los conocimientos a través del sentido, nunca se podrá dudar de ciertas «percepciones» firmísimas que el ánimo posee por sí mismo ("per seipsupl»). ${ }^{85}$ El sujeto subsiste en cuanto tal. Nunca desaparece como sujeto de realidad y de verdad. Pues aunque desapareciera, siempre sería verdad que existió. $Y$, en todo caso, reaparece al pensar e incluso frente a cualquier engaño 0 error, pues, si me equivoco, soy. ${ }^{86}$ Ante mi pensamiento, deseo, etc., reaparece siempre un yo obs-

79 «Sicut enim novi me esse, ita novi etiam hoc ipsum, nosse me» (De civ. Dei, XI, 26). Reconoce la realidad existente y la subjetividad autocognoscente del yo.

80 De b. vita, 2, 7; Enchir., $20,7$.

81 Solil., II, 2: «Erit igitur veritas etiamsi mundus intereat».

82 De lib. arb., II, 3,7 .

83 De vera rel.; 39, 73: «Omnis qui se dubitantem intelligit, verum intelligit, et de hac re quam intelligit, certus est; de vero igitur certus est. Omnis igitur qui utrum sit veritas dubitat, in seipso habet verum unde non dubitet...»

84 De Trin., X, 10, 13-14: «Et nulli est dubium, nec quemquam intelligere qui non vivat, nec quemquam vivere qui non sit». «Vivere se tamen et meminisse et intelligere et velle et cogitare et scire et iudicare quis dubitet?»

85 De Trin., $\mathrm{XV}, 12,21$.

86 «Si enim fallor, sum. Nam qui non est, utique nec falli potest; ac per hoc sum, si fallor. Quia ergo sum si fallor, quo modo esse me fallor, quando certum est me esse, si fallor?... Consequens est autem, ut etiam in eo quod me novi nosse, non fallar» (De civ. Dei, XI, 26). Cf. Doull, F. A., «Si enim fallor, suml: the logic of Certainty in St. Augustine and Descartes», en Studia Patristica, vol. XVIII, 4, Lovaina, Peeters, 1990, 44-48. Indica semejanzas y divergencias, alguna de ellas, inexacta (p. 46). También, Gouhier, H., Cartésianisme et Aulgustinisme au XVIle siècle, París 1978. 
tinadamente real, inscrito inevitablemente en el ser, como sujeto de existencia y de verdad. Y esta certeza se nos da por autoconocimiento y reflexión. La inserción del yo en la realidad existente y la de la mente en la verdad aparecen como un hecho originario y primordial, inmune a cualquier intento de supresión. Emergen de su propio naufragio. Resisten a cualquier duda y subsisten en la mente que duda. Pues quien duda sabe, y quien duda es ${ }^{87}$ Pero la verdad no es fruto de la propia duda, como pensará Descartes. ${ }^{88}$ Porque Agustín no parte, en realidad, de la duda sino de la verdad (M. F. Sciacca)..$^{89}$

Todo esto lo reconoce el espíritu mediante una capacidad decisiva de la propia interioridad anímica: su poder reflexivo.$^{90}$ Hablamos, por ello, de interioridad reflexiva, de reflexión (como acto) o de reflexividad (como capacidad, poder, «vis», o propiedad del espíritu). Terminología, es cierto, poco empleada —o quizá nunca - por los antiguos y por Agustín..$^{91}$ La utilizaremos aquí en cuanto responda fielmente (no tanto a sus palabras cuanto) a su doctrina, con aquella libertad con que los filósofos se suelen expresar. ${ }^{92}$ Por encima de palabras y rótulos, permanece la pregunta: ¿qué es realmente esa reflexión que en estos argumentos opera y que todos ellos suponen? ¿La estudió a

87 «...quandoquidem etiam si dubitat, vivit; si dubitat, unde dubitet meminit; si dubitat, dubitare se intelligit; si dubitat, certus esse vult; si dubitat, cogitat; si dubitat, scit se nescire; si dubitat, iudicat non se temere consentire oportere. Quisquis igitur aliunde dubitat, de his omnibus dubitare non debet; quae si non essent, de ulla re dubitare non posset» (De Trin., $\mathrm{X}, 10,14)$.

88 «No surge la verdad de la duda, sino que esta última es posible porque que el alma dude significa que ya está de alguna manera en la verdad» (Forment, E., «La certeza...», ver bibliogr. final, 302).

89 Por su radicación originaria en la verdad, el alma posee certeza de su yo y se instala en ciertas verdades a todos los razonantes comunes. Son las verdades primeras del espíritu, «illas interiores regulas veritatis» (De lib. arb.,II, $12,34$. También, II, 8, 20). Agustín suele llamarlas «leges». Y enumera las de la dialéctica («disciplina disciplinarum»), las de los números, las reguladoras de la justicia y el derecho, de la belleza o estéticas y las de la ética, relativas al bien y al destino. Añade otras más: la ley eterna, la idea de felicidad... Son autónomas respecto de lo exterior-inferior. No provienen, pues, del sentido. Le competen más bien como pertenencias originarias, vinculadas a su misma naturaleza e inscritas (insitum) en ella. Como «propiedades» primordiales del espíritu, constituyen el círulo infranqueable de la verdad.

90 He aquí un brevísimo comentario a esos argumentos: 1) tienen un doble alcance, ontológico y gnoseológico, al ratificar la certeza del yo en cuanto sujeto de existencia y como sujeto de su propia certeza. 2) Ambas dimensiones conjuntamente constituyen la certeza de la verdad, la cual no es otra certeza más, añadida a estas. 3) La argumentación explicita como cierta la noticia, "nosse se», de existencia que el alma tiene de sí misma, mientras ama «cogitare se»o la indagación «definitoria» de su naturaleza. 4) Recurre a hechos primordiales del sujeto para mostrar cómo todos ellos implican la certeza radical de ser, vivir, pensar. 5) La formulación de estos argumentos reflexivos fue madurando en Agustín, desde sus primeros escritos (Soliloquios) hasta su expresión más fundamentada, en De Trinitate y en De civitate Dei. 6) El supuesto común a todos es la capacidad reflexiva del espíritu, lo que permite el autoconocimiento del alma.

91 «Históricamente, el término »reflexión« es mucho más reciente que la cosa designada con este término. La cosa es tan antigua como la filosofía misma, pues ninguna dirección esencial de la filosofía se desenvuelve sin aquella forma específica del pensamiento que se llama reflexións (Krings,. H.-Baumgartner, H. M.-Wild, Chr., Conceptos fundamentales de filosofía, vol. III, Barcelona, Herder, 1979, 262). Algo particularmente válido en el interiorismo reflexivo de Agustín. Reflexividad no es término oficialmente acepto para nuestros diccionarios académicos. Sí aparece tímido en los especializados, como el de J. Ferrater Mora (vol. IV, Madrid, Alianza, 1984, $5^{a}$ ed., 2811). En algún caso aislado usa Agustín la expresión «reflexus ad», en el sentido de dirigir la atención hacia algo. No coincide con el sentido estricto que nosotros le damos como vuelta del yo sobre el yo en autorrespectividad cognoscitiva (cf. In $l o$, 23,11 ).

92 «Liberis enim verbis loquuntur philosophi» (De civ. Dei, X, 23). El hecho de la reflexión no recibe en Agustín una denominación específica. Por tanto, salvada la justeza y el rigor de los conceptos, vale aquí un principio del propio Agustín: «Licet enim cuique rei cognitae, quae nullum habeat usitatum nomen, quodlibet nomen imponere» (De div. qq. 83, q. 46: De ideis, 1). 
fondo el propio Agustín? ¿Qué se sabe hoy de ese «poder» de la mente? ${ }^{93}$ ¿Qué modalidades presenta? Su método reflexivo de la certeza se esclarece examinando la idea de reflexión que subyace al autoconocimiento del espíritu. Sólo caben aquí unas indicaciones básicas, comenzando por la investigación actual.

1. Historiografía. Desde los años treinta del pasado siglo, la investigación examina, junto a procesos y actos, la facultad superior del conocimiento. ${ }^{94}$ La doctrina de Agustín sobre el autoconocimiento y la reflexión se inscribe en toda una amplia «filosofía del espíritu», con su visión del hombre. Descuella aquí la idea de memoria, perfilada ahora en todo su relieve teórico. ${ }^{95}$ Esto hizo que a mediados del pasado siglo cobrara nuevo auge el estudio de este interesante problema. ${ }^{96}$ Marca todo un hito la conocida investigación de M. Schmaus. ${ }^{97}$ Aportaciones recientes trazan el mapa de cuanto hoy se sabe de su «filosofía del espíritu». Destacan, junto a otros esclarecimientos indirectos sobre la interioridad, la gnoseología en general, etc., las dos obras recientes de L. Hölscher y de J. Brachtendorf. 98

2. Terminología. Agustín no mantiene una terminología fija. ${ }^{99}$ Con gran variedad de nombres, designa en diversos momentos los matices capitales del conocimiento. ${ }^{100}$ Coincidentes, en cierto

93 Agustín emplea la expresión «potentias animi humani» (Ep. 118, 3, 15).

94 En $1930 \mathrm{~F}$. Amerio tocaba este problema y hablaba de un «principio de autoconciencia». Ese mismo año, los Baeunker Beiträge (Supl. III, 1) incluían un artículo de J. Geyser sobre la teoría de Agustín acerca del autoconocimiento del alma humana. Y F.-M. Sladeczek, en un estudio en Scholastik, 5(1930), 329-356, intentaba demostrar que el autoconocimiento del espíritu es el fundamento de la filosofía para Agustín. Son sólo tres ejemplos.

95 Cf. Capánaga, V., «La estructura ontológica de lâ memoria Dei», en Estudio agustin., 20(1975), 367-392.

96 He aquí algunos ejemplos. El concepto mismo de «espírtu», en el comentario mayor al Génesis, lo estudiaba J. H. Taylor, en The Mod. Schoolman, 26(1948-1949), 211-219. En 1957, A. Rigobello confrontaba en Agustín teoría del conocimiento y fenomenología del espíritu, en Augustinus, 2(1957), 241-247. El año siguiente, L. Cilleruelo examinaba la interioridad y la reflexión en Religión y Cult., 3(1958), 85-108. Y también el estudio de Capánaga, V. «Conocimiento y espíritu según San Agustín», en Augustinus, 3(1958), 177-192. Reflexión, inmaterialidad y filosofía del espíritu los relacionan también H. Hornstein (Düsseldorf 1960) y Seifert, F., Seele und Bewusstsein..., Munich-Basilea, Reinhardt, 1962.

97 Schmaus, M., Die psychologische Trinitätslehre des heiligen Augustinus, Münster, Aschendorff, 1967.

98 Hölscher, L. The Reality of the Mind. Saint Augustine's Philosophical Arguments for the Human Soul as a Spiritual Substance, Routledge \& Keagan Paul, Londres-Nueva York, 1986. Importante estudio que acaba de ser traducido al alemán, Heidelberg, C. Winter, 1999. Interesa particularmente su cap. Ill sobre el autoconocimiento del alma, entendido aquí como argumento de la conciencia de su espiritualidad por parte de Agustín. Brachtendorf, J., Die Struktur des menschliches Geistes nach Augustinus. Selbstreflexion und Erkenntnis des Geistes in «De Trinitate», Hamburgo, Meiner, 2000. Tengo presente el primero de estos libros. No he llegado a conocer el segundo. También: O`Daly, G. J. P., Augustine's Philosophy of Mind, Berkeley, CA., Univ. of Calif. Press, 1987.

99 Cf. Gilson, É., Introduction..., 56-57; Sciacca, M. F., San Agustín..., 216-218; 403-404; Kowalczyk, St., «La conception de l'homme chez Saint Augustin», en Giorn. d. Metaf., 27(1972), 199-211, espec. p. 200, con juiciosas indicaciones en estrecho contacto con los textos; Santi, G., «Conoscenza e memoria nella filosofia di Sant'Agostino», en Aquinas, 30(1987), 401-439, espec. pp. 426-431.

100 Por ejemplo, estos: 1) la interioridad e inmediatez intuitiva, indicada con «mens», « intellectus», «intelligentia». Cf. Capánaga, V., «La doctrina agustiniana de la intuición», en Augustinus, 23(1978), propio de la «ratio» 71-86. 2) La discursividad o movimiento «distinguendi et connectendi potens» (De ord., II, 11, 30 y todo el contexto). 3) La capacidad de juicio, con el «animus iudex» o la "ratio iudex». «Sed sublimioris rationis est iudicare...» (De Trin., XII, 2, 2). Pero habla también de «animae iudicium» (De Gen. litt., imperf. liber, V, 24). 4) La iluminación, del «intellectus» (cf. Ep.147, 18, 45; In ps. 31, 9: «intellectus» equivale a «intelligentia»), al que pertenece la «sapientia». 5) La reflexividad o autoconocimiento de la mente o del ánimo: «mens non videtur nisi mente» (De Gen. litt., XI, 21). 6) La autononía de la «mens», respecto de lo inferior-exterior, por poseer y seguir leyes o reglas «sui itris» (De Trin., IX, 6, 10). Es toda una gama de matices con equivalencias variables, acentuadas aún más cuando Agustín intenta decirnos qué es lo «superior in honinte». 
modo, con las grandes dimensiones del ser humano. ${ }^{101} \mathrm{Y}$ aunque su uniformidad anda lejos de ser plena, ya Tomás de Aquino veía señalada una única facultad superior de conocimiento. ${ }^{102}$ En consecuencia, atenernos a la palabra «spiritus» podría resultar equívoco. ${ }^{103}$ Con «filosofía del espíritu» se menta aquí la facultad cognoscitiva superior en cuanto capaz de autoconocerse al volver sobre sí mediante el giro interior de la reflexión.

3. El punto de partida. La victoria sobre el materialismo abrió el dominio del espíritu y las facultades de lo incorpóreo. ${ }^{104}$ Esto permitió a Agustín, entre otros logros, una gnoseología que define (y es definida, en buena parte, por) la relación entre conocimiento y corporeidad. Desde este punto de vista, sus principios más pertinentes a nuestro problema son: a. el conocimiento inteligible acontece lejos del sentido y de lo corpóreo. ${ }^{105} \mathrm{~b}$. Lo corpóreo lo conoce la mente con el cuerpo. ${ }^{106} \mathrm{c}$. Lo inteligible lo conocemos directamente, sin mediación de cuerpo. ${ }^{107} \mathrm{~d}$. El sentido no conoce el sentido (y menos aún, la mente). ${ }^{108} \mathrm{e}$. Sólo la mente conoce la mente. ${ }^{109}$ La reflexividad se revela, pues, como atributo exclusivo de la mente ¿Cómo explicarlo?

101 Además del cuerpo, integran el ser del hombre el «animus», «anima», «spiritus». Sorprende la expresión «ego animus» (Confess., X, 6, 9), que en Descartes sería más bien «ego ratio», también empleada por Agustín (Solil., I, 6, 12). El alma oscila entre su función animadora de la corporeidad, que los animales comparten, o la cosa más excelsa del mundo (cf. resonante himno de alabanza, en De quant. an., 34, 77, eco de Plotino, En. IV, 4, 1). El «animus», como en Varrón, es el «summus gradus animae», del que los animales carecen (De civ. Dei, VII, 23, 1; De Trin., XV, 1, 1).

102 «Ratio ergo et intellectus et mens sunt una potentia» (S. theol., I, 79, 8). Comenta el texto de Agustín en que lo sobresaliente del hombre respecto del animal «est ratio, vel mens, vel intelligentia, vel si quo alio vocabulo commodius appellatur» (De Gen. litt., III, 20, 30).

103 La oscilación es aquí notable. Bajo influjo estoico (estudiado por G. Verbeke, W. A. Schumacher, A. Solignac...) y paulino (1 Cor., 14, 14), Agustín corrige el «monismo» platónico, que identifica con el alma sola toda la realidad del hombre (Leyes, 959 a-b; En., I, 1, 7, Tuscul., I, 52), admitiendo también el cuerpo ("Quisquis ergo a natura humana corpus alienare vult, desipit», De an. et eius orig.,IV, 2, 3). E incluye, además, el espíritu (al igual que Porfirio), como intermediario entre alma y cuerpo. De este modo, «... tria sunt quibus homo constat, spiritus, anima et corpus» (De fide et symb., 10, 23). Pero no es clara su definición del espíritu (De Gen litt., XII, 7, 16; XII, 9, 20). Es difusa y amplia su idea general (De Trin., XIV, 16, 22). Es equívoca al aplicarse a Dios y al hombre, puesto que la divinidad carece de cuerpo y de alma (ibid., XV, 5, 7). La diferencia con el alma no es nítida (aunque dedica al tema el capítulo 22, libro IV, de De nat. an. et eius orig.). $\mathrm{Ni}$ tampoco entre mente y espíritu (De Trin., XIV, 16, 22). La cosa se complica cuando equipara animus, anima, spiritus. O bien: mens, spiritus, ratio (De lib. arb., I, 9, 19). No queda claro si el espíritu es lo superior en el hombre o lo más próximo a la corporeidad y sus imágenes 0 , con Porfirio, una instancia intermediaria entre ambas.

104 Su materialismo, que sólo le permitía entender lo material y le impedía realmente pensar, lo describe él mismo, junto a su lucha en este punto (Confess., VII, 1, 1). Los platónicos le revelaron el mundo no-material e inteligible. Abrieron así toda la gama, los "gradus", del ser. Y le dieron acceso al mundo anímico de una inmaterial interioridad (cf. extenso razonamiento sobre la incorporeidad anímica en De Gen. litt., VIl, 15, 21ss.). Enuncia repetidamente la superioridad del alma sobre el cuerpo: De immort. an., 15, 24; De div. qq. ad Simpl., I, 2, 18. Entona un «himno» al alma y sus poderes: De quant. an., 34, 77; De mus., VI, 10, 28; Confess., X, 17, I. «Anima omnis omni corpore est melior» (De mus., VI, 13, 41). Y tiende, en su juvenil platonismo, a reducir el hombre a su alma... Exagera el influjo de Plotino R. J. O'Connell. Más equililibrado es el libro de Coutourier, L., La structure essentielle de l'homme d'après S. Augustin, Roma 1964.

105 Al conocer lo inteligible «longe removeor a corpore» (De lib. arb., II, 11, 30). «...animus... cum intelligere vult, a corpore avertitur». No le ayuda. Y bastante es que no lo impida (De immort. an., 1, 1).

106 «Per oculos enin corporis corpora videmus» (De Trin., IX, 3, 3). «Per corpus corpora videre» (ibid., IX, 6, 11). «...per sensum corporis discimus corpora..." (ibid., IX, 11, 16).

107 Lo inteligible «a nobismetipsis intus aspicitur in animo sine corpore» (Ep. 147, 1, 6).

108 «Oculus carnis alia videt, se non potest. Intellectus autem et alia intelligit et seipsum» (In Io., 47, 3). Del sentido excluye Agustín la verdad (De div. qq. 83, q. 9), la competencia de juzgar (De civ. Dei, XI, 27, 2) y la reflexividad.

109 «Mens non videtur nisi mente» (De Genl. litt., XI, 21). «Itaque mens cum seipsam cognoscit, sola parens est notitiae suae. Et cognitum enim et cognitor ipsa est» (De Trin., IX, 12, 18). 
4. Autoconocimiento y reflexión. El alma se autoconoce. ${ }^{110}$ La mente ve la mente. Se refleja «tamquam in speculo», pero sin el espejo material que el cuerpo precisa para verse. ${ }^{111}$ Con-vierte su ojo interior desde lo exterior y se pone ante su mirada («in conspectu suo»), se pone ante sí («ante se ipsam») ¿Por qué puede hacerlo la mente y no la piedra? ¿Qué le confiere el poder, «potentia», de volver sobre sí? Reflexividad supone flexibilidad y reflejo, versatilidad, capacidad de doblar y girar sobre sí, autorrespectividad. El alma lo hace por dos razones: su incorporeidad y su autopresencia. ${ }^{112} \mathrm{La}$ mente vuelve sobre sí no espacialmente sino «incorporea conversione». ${ }^{113} \mathrm{La}$ inmaterialidad reaparece en el quicio de la antropología y la gnoseología agustinianas. ${ }^{114} \mathrm{La}$ autopresencia del alma es tesis constante. ${ }^{115} \mathrm{Y}$ esto, dice expresamente Agustín, le permite conocerse. ${ }^{116}$ No se indague como ausente. Reoriente la «intención» desde lo exterior en que vaga, fijela en dirección hacia sí misma y se piense. ${ }^{117}$ En la base del autoconocimiento está, pues, el poder de reconducir hacia sí la «intentio». Por él, la mente, reorientando hacia sí la respectividad que dirige hacia lo exterior, se pone ante su propia mirada ("se in conspectu suo ponit») y es, a la vez, cognoscente y conocido ( ad seipsam nota et noscens dicitur»). Cuando eso ocurre, cuando ella sola produce directamente - y no mediante una imagen— la noticia de sí («sola parens est notitiae suae»), y el sujeto conocedor y el objeto conocido sea ella misma ( $e$ et cognitum...et cognitor ipsa est»), estamos ante una verdadera y propia reflexión de la mente. ${ }^{118}$ En conclusión, Agustín supone, en la base del autoconocimiento anímico y de su propia argumentación antiescéptica, aquello mismo que nosotros denominamos «reflexión». ${ }^{119}$ Veamos ahora sus modalidades.

5. ¿Tres modos de autoconocimiento y de reflexión? Nuestro pensador tematiza expresamente dos en De Trinitate, mientras supone y ejerce otra más en Confessiones. Encuentra muy

110 «... quae magis se novit quam caelum et terram...» (De Gen. litt., VII, 21, 28).

111 «Non est oculus in conspectu suo quandoquidem non conspicit se ipsum nisi speculo obiecto... Quod non fit utique quando se mens in suo conspectu sui cogitatione constituit» (De Trin.,XIV, 6, 8).

112 «Mens ergo ipsa sicut corporearum renum notitias per sensus corporis colligit, sic incorporearum per semetipsam. Ergo et semetipsam per se ipsam novit, quonian est incorporeas (De Trin., IX, 3, 3). Subrayado mío.

113 De Trin. XV, 6, 8.

114 Cf. Hölscher, L., The Reality..., caps. I-II, 11-125.

115 «Secum esse» (De ord., II, 2, 5). «Quid autem propinquius me ipso mihi?» (Confess., X, 16, 25) «Quid enim tam intime scitur, seque ipsum esse sentit, quam id quo etiam coetera sentiuntur, id est, ipse animus?» (De Trin., VIII, 6, 9) «... nec magis quidquam praesens est quam ipsa sibi» (De Trin., XIV, 11, 14), «quadam interiore vera praesentia». «.. sibi semper est praesens». «... sibi praesto est» «Quid tam menti adest, quam ipsa mens?» (De Trin., X, 7, 10). Nada le es más próximo (Ibid., X, 4, 6). Esta proximidad, el estar más disponible y «a mano», esta autopresencia, la vuelve diáfana ante su propia mirada. Cualquiera otra cosa le es distinta o le cae lejos. Pero ella siempre está para sí y cabe-sí. Asiste a sí misma: «secum est». Ser y ser-se. La verdad de sí misma es privilegiada por ser inmediata. No la conocemos a través de instrumento. El alma la intuye directamente y per se. Sólo necesita reconducir la mirada por re-flexión.

116 «Cognoscit seipsam; nec ob aliud quam eo quod sibi praesens est» (De Trin., X, 9, 12). Subrayado mío.

117 «Cognoscat ergo seipsam, nec quasi absentem se quaerat, sed intentionem voluntatis qua per alia vagabatur statuat in se ipsa et se cogitet» (De Trin., X, 11,8).

118 «... can we speak of self-reflection in the proper sense» (Hölscher, L., The Reality..., 291). Las palabras del texto, que cita también Hölscher, se hallan en De Trin., IX, 10, 18. Pero, incongruentemente, las restringe a la sola "cogitatio».

119 Aunque no la nombra, Agustín supone la reflexión como medio de autorrecuperación del alma. Y le da también un marcado sentido ético. Siendo la mente interior ("clum sit mens interior»), de algún modo sale de sí misma ("quodam modo exit a semetipsa») cuando por el sentido conoce lo exterior y retiene sus imágenes. Pero puede reconducir su «intentio" y volver sobre sí (cf. De Trin.,X, 8, 11). Diríamos que se pierde y se aliena en lo desemejante («in regione dissimilitudinis»). Pero de su incorporeidad y autopresencia natural deriva la capacidad de retorno sobre sí. Este giro, capaz de reorientar la «intentio", poner la mente ante sí misma («in conspectu suo») y recuperarse de su propia exterioridad vacua e inane, es justamente la reflexión, que posibilita en su raíz la «con-versión». 
admirable («permirabile») que la mente se conozca y se desconozca, a la vez, al indagarse a sí misma amando autosaberse. ${ }^{120}$ Examina tan notable cuestión («mirabilis quaestio») en De Trinitate, libros IX y X, en dos intentos bien marcados por él, bajo el supuesto platónico y bíblico de la semejanza con Dios, homiósis Theoú. ${ }^{121} \mathrm{Y}$ busca afanosamente, en un artificioso juego triádico, «tréboles» del hombre interior que espejen el abstruso misterio trinitario. ${ }^{122}$ De no ser por su horizonte antropológico y su sentido trascendente, se diría que nos encontramos ya en pleno trinitarismo hegeliano. Con cierto devaneo retórico y menor fárrago bíblico del acostumbrado, distingue nítidamente dos grandes modos de conocimiento de sí: « se nosse» $\mathrm{y}$ «se cogitare». ${ }^{123}$ En rigor de palabra, habrán de traducirse como autoconocimiento «noticial» y autoconocimiento «cogitátivo». Su análisis marca un punto álgido en el pensamiento de Agustín ${ }^{124}$ ¿Cómo entiende ambas nociones y qué implican para el concepto de reflexión? Abreviando su profundo y denso estudio, digamos que el autoconocimiento noticial es como el contacto primordial, intuitivo y natural, de la mente consigo misma. ${ }^{125}$ No rebasa la experiencia inmediata ni el dominio fáctico. Todo está allí implícito. Y cuando giramos la atención a otra cosa, la propia memoria custodia nuestra mismidad y su presencia. ${ }^{126}$ Pues la distensión del alma en tres éxtasis temporales (presente de pasado -0 recuerdo — presente de presente -0 atención - y presente de futuro - o expectación de espera y esperanza-) la mantiene en el perpetuo presente de su presencia a sí misma. Es la «memoria sui», un nudo de identidad y de presencia retenida del alma a sí misma. ${ }^{127}$ La noticia de sí, «nosse se», permite reconocer la certeza de la propia existencia. Agustín enuncia aquí algunos de los argumentos antes indicados. Sabemos que somos una sustancia existente, pero desconocemos su naturaleza. Ignoramos qué es. Nos conocemos y nos desconocemos, a un tiempo, cuando el amor nos impulsa a indagarnos. Aparece así un célebre trébol: «mens», «notitia», «amor». 128

120 «Et hoc quidem permirabile est nondum se nosse et quam sit pulchrum se nosse iam nosse» (De Trin., X, 3, 5). «Ergo se ipsam quemadmodum quaerat et invenjat, mirabilis quaestio est quo tendat ut quaerat aut quo veniat ut inveniat» (ibid., X, 8, 1I). «... cum se quaerit ut noverit, quaerentem se iam novit. Iam se ergo novit. Quapropoter non potest omnino nescire se, quae dum se nescientem scit, se utique scit... Quapropter eo ipso quo se quaerit, magis se sibi notam quam ignotam esse convincitur. Novit enim se quaerentem atque nescientem dum se quaerit ut noverit» (ibid., X, 3, 5). Saberse desconocida e indagarse es autoconocerse. «Cum ergo quaerentem se novit, se utique novit» (De Gen. litt., VII, 21).

I21 Cf. Sullivan, J. E., The Image of God..., Dubuque, Io., The Priory Press, 1963.

122 Iturrioz, I., «El trinitarismo en la filosofía de San Agustín», en Rev. esp. teol., 3(1943), 89-129. Rief, J., Der Ordobegriff des jungen Augustimus, Paderborn, Schöning, 1962, donde se analizan las tríadas vestigiales.

123 «Aliud est se nosse, aliud se cogitare» (De Trin., X, 5, 7).

124 Ch. Boyer veía en el trinitarismo un compendio del pensamiento de Agustín. Parecido entusiasmo expresa M. F. Sciacca acerca del esclarecimiento de la naturaleza humana en De Trinitate (cf. San Agustin..., 443). M. Schmaus exalta el análisis del espíritu. Y descubre aquí toda una antropología filosófica, en la que, a juicio de L. Hölscher, la intención teológica no resta valor a su altura filosófica (cf. The Reality..., 127). Y menciona el juicio de J. Seifert según el cual se contiene aquí el más poderoso análisis del alma de toda la filosofía de Occidente. Sin duda, el hombre sale de la comparación mutua más beneficiado que Dios, cuyo arcano y trinitario misterio sigue siendo tan arcano, tan estricto y tan abstruso misterio como siempre fue, antes, en y después de su revelación y de los artificiosos tréboles de Agustín.

125 «Aliquid pertinens ad eius naturam est conspectus eius...« (De Trin., XIV, 6, 8). «Poseemos un autoconocimiento tan natural, que casi se confunde con la naturaleza». Y Io tenemos «por intuición natural» (Cilleruelo, L., «La Memoria sti...», 486, 487).

126 «... notitia vero cuiusque rei quae inest menti, etiam quando non de ipsa cogitatur, ad solam dicatur memoriam pertinere» (De Trin., XIV, 6, 9).

127 Cf. Cilleruelo, L., art. cit., cuyos datos repito: «La Memoria sui», en Giom. d. Metaf., 9(1954), 478-492.

128 «Igitur ipsa mens et amor et notitia eius, tria quaedam sunt, et haec tria unum sunt» (De Trim., IX, 4, 4). 
El autoconocimiento cogitativo, por el contrario, es definitorio. ${ }^{129}$ Agustín lo presenta con los rasgos del verdadero saber, que siempre es conocimiento explícito, «esencial» y radical, saber de naturaleza, insiste él mismo. ${ }^{130}$ Por este intento, la mente hace de sí misma cuestión, buscando su ser. $^{131}$

¿Qué hay en todo esto de verdadera reflexión? En un cierto texto, Agustín parece insinuar que sólo hay auténtica presencia de la mente a sí misma en el autoconocimiento cogitativo. Tal es, dice él, la fuerza («vis») de la «cogitatio». ${ }^{132}$ Más aún. Parece que siendo inmediato, natural y presencial, el autoconocimiento noticial no inplicaría una verdadera «reflexio» de la mente. Y que sólo la habría en el segundo momento cogitativo, por el que la mente se pone ante sí misma, «se in conspectu suo». Sin embargo, Agustín mismo subraya la respectividad a sí misma de la mente en el conocimiento noticial, matiz suficiente para que haya reflexionn. ${ }^{133}$ Estimo, con L. Hölscher, que la reflexión se da siempre que la mente vuelva sobre la mente, haciendo que sujeto conocedor y objeto conocido coincidan con ella misma. Lo que viene a decir que la reflexión está en la base del autoconocimiento, tanto del cogitativo como del noticial. Los argumentos de certeza son, por eso mismo, reflexivos. La mente reconoce con ellos su propia autonoticia sin salir del ámbito subjetivo del yo o más bien volviendo sobre el evento interior de la verdad para fundamentarla como cierta. Pero hay más. Un pensador ha de ser interpretado por lo que dice y por lo que hace o supone cuando filosofa.

6. La «reflexión fenomenológica». Un nuevo tipo de reflexión debiera añadirse a estos dos, habida cuenta de lo que en sus Confesiones Agustín hace aunque no lo dice. Allí practica un nuevo tipo de autoconocimiento y reflexión capaz de mostrar la dinámica del espíritu. Este nuevo giro a la realidad subjetiva supone la «notitia» anímica, sin pretender siempre la «cogitatio sui». El resultado es toda una analítica de ese «grande profundum» que es el hombre interior. ${ }^{134}$ Realiza un fino autoanálisis de la realidad anímica en general y del conocimiento de la mente en particular. Distingue y correlaciona los «componentes» del alma mirando a sí misma. La mente ve a la mente. Las Confesiones son teoría y práctica de la interioridad. El ejemplo más célebre es quizá la exploración de los «estratos» de la memoria. Y vuelve también, en giro reflexivo, ascensional y místico, sobre el «itinerarium mentis» que culmina en la verdad. Y hay, además, una verdadera «cogitatio» del alma, aunque indirecta, a propósito del tiempo, revelador de su èstructura distensiva radical. Esta indagación conjunta se interpreta hoy como una auténtica fenomenología del mundo interior. Las Confesiones son, como queda dicho, el ejercicio mismo de la gnoseología interiorista de

129 Cf. De Trin., IX, 6, 9. Utiliza su esquema preferido de lo mutable e inmutable. La «cogitatio» intenta un saber definitorio, permanente, esencial, y alcanzar la naturaleza: «... de animi sui natura cogitare» (ibid., XIV, 5, 8).

130 «... cogitare naturam» (De Trin., X, 10,13) «... de natura mentis agitur» (ibid., X, 10, 14). Y siempre va implicada su sustancia: «Nullo modo autem recte dicitur sciri aliqua res, dum eius ignoratur substantia» (ibid:, $X, 10,16$ ). Además de este sentido reflexivo, Agustín entendió la palabra "cogitatio» en sentidos muy diversos y quizá un tanto oscilantes e imprecisos, como, por ejemplo, en De Trin., XV, 9, 16 (cf. Morán, J., La teoría..., 177, nota).

131 Es un verdadero autosaberse: «Mens igitur quando cogitatione se conspicit, intelligit se et recognoscit: gignit ergo hunc intellectum et cognitionem suam» (De Trin., XIV, 6, 8). Atención al «se conspicire».

132 «Tanta est tamen cogitationis vis ut nec ipsa mens quodam modo se in conspectu suo ponat nisi quando se cogitat, ac per hoc ita nihil in conspectu mentis est nisi unde cogitatur, ut nec ipsa mens, qua cogitatur quidquid cogitatur, aliter possit esse in conspectu suo nisi se ipsam cogitando» (De Trin., XIV, 6, 8).

133 Un ejemplo: «Et notitia, quamvis referatur ad mentem cognoscentem vel cognitam, tamen et ad se ipsam nota et noscens dicitur; non enim sibi est incognita notitia, qua se mens ipsa cognoscit» (De Trin.,.IX, 5, 8). Este movimiento de sí hacia sí, esta autorrespectividad cognoscitiva es, justamente, la «reflexio». 0 , sin duda, la supone.

134 «Grande profundum est ipse homo» (Confess., IV, 14, 22) «... nec ego ipse capio totum quod sum» (ibid., X, 8, 15). 
Agustín. Sólo escasamente tematizan su propia metodología, el procedimiento seguido. Lo suponen. Pues su vía de interioridad y de retorno para explorar el yo, en giro sobre sí mismo, practica un método específico de autoconocimiento y reflexión. Su análisis comporta un espejamiento continuo de la realidad del yo. El sujeto que conoce y el objeto conocido son uno mismo: el espíritu, la mente o el «ánimo». Para este tercer tipo de autoconocimiento y tercer tipo de la "reflexio» habrá de seleccionarse un nombre actual, que Agustín no le dio. Podría llamarse «reflexión fenomenológica». ${ }^{135}$

Conclusión. Investigado el problema agustiniano de la certeza y su argumentación reflexiva, desde el autoconocimiento del yo, se concluye que la gnoseología interiorista, reflejada en la vivencia y el relato de Agustín, abre de suyo la vía de la reflexividad. Ella hace posible la fundamentación de la verdad en célebres argumentos que presentamos con brevedad. Y queda mostrado que la interioridad reflexiva, estudiada por Agustín en toda una «filosofía del espíritu», abarca, en realidad, tres tipos generales de "reflexio». Son: la reflexión noticial, cogitativa y fenomenológica.

Agustín Uña Juárez

Universidad Complutense de Madrid

Facultad de Filosofía A

Departamento de Filosofía III

Ciudad Universitaria

28040 Madrid

\section{BIBLIOGRAFÍA}

Biolo, S., La coscienza nel «De Trinitate» di S. Agostino, Roma, Univ. Gregoriana, 1969.

Blanchet, T, L., Les antécédents historiques du «Je pense, donc je suis», París, Alcan, 1920.

Boyer, Ch., L'idée de vérité dans la philosophie de Saint Augustin, París, Beauchesne, 1921, 1943, $2^{\circ}$ ed.

—, Christianisme et néo-platonisme dans la formation de Saint Augustin, ibid. 1920.

—, Sant'Agostino filosofo, Bolonia, Pàtron, 1965.

Brachtendorf, J., Die Struktur des menschliches Geistes nach Augustinus. Selbstreflexion und Erkenntnis

Gottes in «De Trinitate», Hamburgo, Meiner, 2000.

Castex, M. N., «La memoria metafísica según el libro X de las Confesiones», en Sapientia, 19(1964), 9-25.

Cilleruelo, L., «La Memoria sui», en Giorn. d. Metaf., 9(1954), 478-492.

Curley, A. J., Augustine's critique of skepticism. A study of Contra Acadenicos, Francfort, Lang, 1997.

De Finance, J., Cogito cartésien et réflexion thoniste, París 1946.

Derisi, O. N., «Verdad y certeza en San Agustín», en La ciudad de Dios, 166(1954), 323-341.

135 Hoy se considera apropiado este nombre. El reciente estudio de Hermann, F.-W. von, Augustinus und die phänomenologische Frage nach der Zeit, Francfort, Klostermann, 1992 muestra que la reflexión agustiniana sobre la temporalidad y el tiempo en las Confesiones sigue un método fenomenológico. Hermenéutica retomada por E. Husserl y M. Heidegger en estrecho contacto con el propio Agustín. Y, por cierto, quienes absolutizan al Agustín teólogo pueden leer aquí que la meditación del tiempo en el libro XI de las Confesiones, caps. 14-28, constituye «ein Meisterwerk philosophischer Literatur» (p. 13). 
Ferreti, S., «Il giudizzio di Sant'Agostino sulla Nuova Accademia tra scetticismo ed esoterismo», en Filosofia, 41(1990), 155-183.

Forment, E., «El problema del «cogito» en san Agustín», en Augustinus, 34,133(1989), 7-30.

—, «La certeza en la metafísica de la verdad de san Agustín», en Rev. de Filos. (México), 20(1987), 290-303.

Frutos, E., «Realidad y límites de la resonancia de San Agustín en Descartes», en Augustinus, 13(1968), 219248.

Gilson, É., Introduction à l'étude de Saint Augustin, Paris, Vrin, 1969, $4^{\mathrm{a}}$ ed.

Hadot, P., Arts libéraux et philosophie dans la pensée antique, París, Ét. Augustin., 1984.

Hessen, J., Augustins Metaphysik der Erkenntnis, Leiden, Brill, 1960, $2^{\mathrm{a}}$ ed.

Hölscher, L., The Reality of the Mind. St. Augustine's..., Londres-Nueva York, Routledge \& K. Paul, 1986.

Lancel, S., Saint Augustin, París, Fayard, 1999.

Marrou, H.-I., Saint Augustin et la fin de la culture antique, París, Boccard, 1958, $4^{\mathrm{a}}$ ed.

Menn, St., Descartes and Augustine, Cambridge, Univ. Press, 1998.

Morán, J., La teoría del conocimiento en San Agustín, Valladolid, Archivo Agustin., 1961.

Mosher, D. L., «The argument of St. Augustine's Contra Acadenticos», en Augustin. Stud., 12(1981), 89-113.

Muñoz Vega, P., Introducción a la síntesis de San Agustín, Roma, Univ. Gregoriana, 1949.

Neiman, A. M., «The Arguments of ... Contra Academicos», en Mod. Schoolman,59(1982), 255-279.

Neuhausen, K. A., «Academicus sapiens. Zum Bild des Weisen in der Neuen Akademie», en Mnemosyne, 40 (1987), 353-390.

O'Connell, R. J., St. Augustine's early theory of man..., Cambridge, Mass., Harvard Univ. Press, 1968.

O Meara, J. J., The Young Augustine. The growth of St. Augustine's mind..., Londres, Longmans, 1954.

Pegueroles, J., San Agustín.Un platonismo cristiano, Barcelona, PPU., 1985.

Sanabria, J. R., «Agustín de Hipona, filósofo de la interioridad y del amor», en Rev. Filos. (México), 20,5859(1987), 118-156.

Schmaus, M., Die psychologische Trinitätslehre des heiligen Augustinus, Münster, Aschendorff, 1967.

Schöpf, A., Wahrheit und Wissen. Die Begriindung der Erkenntnis bei Augustin, Munich, Pustet, 1965.

Sciacca, M. F., San Agustín, Barcelona, Miracle, 1955.

Smalbrugge, M. A., «L'argumentation probabiliste d'Augustin dans le Contra Academicos», en Rev. d. Ét. Augustin., 32(1986), 41-55.

Trapè, A., S. Agostino. L'uomo, il pastore, il mistico, Fossano, Esperienze, 1976.

Uña Juárez, A., Cántico del Universo. La estética de San Agustín, Madrid 2000.

Zekiyan, B. L., «La struttura onto-psicologica dell'interiorismo agostiniano e la memoria Dei», en Filos. oggi., 1(1978), 270-335. 